\title{
Subjective Well-Being and Individual Material Situation in Four Countries of Central Europe ${ }^{1}$
}

\author{
Jan Švorc ${ }^{2}$ \\ Institute of Information Theory and Automation, Czech Academy of Sciences, \\ Praha; University of Economics, Faculty of Management, Praha

\begin{abstract}
Subjective Well-Being and Individual Material Situation in Four Countries of Central Europe. This article deals with the subjective well-being (SWB) and its association with subjective and objective measures of individual material conditions in the Czech Republic, Hungary, Poland, and Slovakia. Material conditions are measured by the level of income; relative income approximated by subjective evaluation of one's own financial situation as compared to most people, as well as to one's own past financial situation; subjective economic strain; financial problems; ability to afford selected items and housing defects. The statistical analysis is based on data sourced from the third and fourth wave of the European Quality of Life Study. The results show that a better material situation as approximated by the given variables is associated with improved SWB in the Czech Republic and Poland. In Hungary, people in high-income groups are not on average happier and more satisfied with their lives than people in low-income groups, and people who are able to make ends meet are not on average happier and more satisfied than those who are unable. In Slovakia, people in high-income groups are not on average more satisfied with their lives than people in low-income groups, and people evaluating their financial situation favourably as compared to most people in their country are not on average happier and more satisfied with their lives than people evaluating it as worse. The subjective financial situation relative to most people and the subjective economic strain seem to be especially important factors.

Sociológia 2018, Vol. 50 (No. 6: 727-759)

https://doi.org/10.31577/sociologia.2018.50.6.27
\end{abstract}

Key words: Subjective well-being; life satisfaction; happiness; income; relative income; material situation; JEL Classification: I31

\section{Introduction}

Throughout human history, philosophers and clerics have warned that material wealth is detrimental to people's life, happiness and salvation. Social sciences turned their attention to happiness and satisfaction only several decades ago and research has proved that material aspects somehow matter. The association of material conditions with happiness and life satisfaction (hereinafter referred to also as "satisfaction") is the research area of this empirical study. The broad goal of this study is to investigate how individual income in both absolute and relative terms, as well as other economic characteristics, are associated with subjective well-being (hereinafter referred to as "SWB") in post-communist central Europe represented by the four structurally, economically and culturally

\footnotetext{
1 This work was supported by the Czech Science Foundation (project 17-08182S).

2 Address: Ing. Jan Švorc, MBA, Institute of Information Theory and Automation, Czech Academy of Sciences, Pod Vodárenskou věží 4, 182 08, Praha 8, Czech Republic. University of Economics, Faculty of Management, Jarošovská 1117/II, 37701 Jindřichův Hradec, Czech Republic. E-mail: svorc3@ seznam.cz
} 
similar countries: the Czech Republic, Poland, Hungary and Slovakia (all references to central Europe in this paper mean only these four countries). Answers to the following three specific questions should be addressed in this paper:

1) Are high-income households on average happier/more satisfied than lowincome households in central Europe?

2) Is individual happiness/satisfaction on average associated with the subjective evaluation of one's own current financial situation in central Europe?

3) Is individual happiness/satisfaction on average associated with other economic characteristics, such as ability to afford selected items, financial problems, housing defects and economic strain in central Europe?

\section{Literature review}

SWB is often used synonymously with happiness as well as with satisfaction in the literature. Veenhoven (2008) is an example of this approach. He defines happiness as "the degree to which an individual judges the overall quality of his life favourably". (Veenhoven 1984: 22) For Veenhoven, the terms happiness and satisfaction are identical meanings of favourable subjective assessment of one's life. Another widely accepted concept of SWB was proposed by Diener et al. (1999). Following Andrews and Withey (1976), Diener distinguished among three general components of SWB: positive affect, negative affect (affective dimension of SWB), and satisfaction judgement (cognitive dimension of SWB). From this perspective, SWB is a "person's cognitive and affective evaluation of his or her life". (Diener et al. 2002: 63) The term "affect" includes both moods and emotions; affects represent people's instant evaluations of events that occur in their lives. (Diener et al. 1999) Diener defines happiness as dominance of positive affect over negative affect ${ }^{3}$. Being happy hence means experiencing pleasant emotions most of the time and feeling negative emotions and moods (anger, stress, etc.) rarely. (Diener Biswas-Diener 2002) Satisfaction includes the satisfaction with various aspects of life, such as job, income, family, leisure (domain satisfaction) as well as the satisfaction with life as a whole. Being satisfied with one's own life means subjectively judging life as meaningful and fulfilling.

People generally tend to think they become happy when they get rich. This belief is widespread and illusory. (Kahneman et al. 2006) The relationship between income and SWB is a very complex topic (Dolan et al. 2008) and the findings are sometimes surprising. The reviews of the evidence are provided, e.g., by Diener (1984) and Diener et al. (1999). Overall, researchers suggest

\footnotetext{
${ }^{3}$ There is still the debate over independence of the positive and negative affects.
} 
that money has a positive, yet diminishing effect on SWB. (Dolan et al. 2008; Diener - Ryan 2009) It is in accordance with the widely accepted economic law of declining marginal utility. The theory suggests that the effect of one's income on SWB weakens with his overall wealth. For example, a study of Diener et al. (1985, cited in Diener - Ryan 2009) showed that the wealthiest Americans experience only a slightly higher SWB level than an average American, and $37 \%$ of them experience even lower SWB that the average American. The authors mostly suggest a positive association between income and SWB, at least to a certain point. It does not necessarily mean that the richest people are the happiest. For example, Mentzakis and Moro (2009: 147) found that higher absolute income increases SWB up to a certain point and that the rich feel only "fairly happy". It seems that absolute income does not buy all levels of happiness. The authors conclude that "high-income groups are less likely to belong in the highest SWB level". Although it seems unlikely that the highest-income groups will be the happiest, a working hypothesis can be derived in two variants as a prediction for research question 1:

1a: People in high-income groups are on average happier than those in lowincome groups in central Europe.

1b: People in high-income groups are on average more satisfied with their lives than those in low-income groups in central Europe.

There are studies suggesting that, instead, relative income matters. There is a broad group of relative standard theories common in the assertion that SWB is a result of a comparison between the actual situation and a certain standard. The standard might be one's past, goals, ideas, other people, etc. (Diener Ryan 2009) Some authors argue that the impact of income depends on these changeable standards derived from expectations, habituation levels, and social comparisons. (Diener et al. 1993) It means that additional income has no effect on SWB if the income of people in the reference group also increases. (Dolan et al. 2008) Clark et al. (2008) suggest that an increase in everyone's income does not cause an increase in people's happiness on average, because of the comparison to others and comparison to oneself in the past. Similarly, based on GSOEP data, Dittmann and Goebel (2010) identified that satisfaction of an individual in Germany is lower when he lives in a neighbourhood with a socioeconomic status higher than his own, and vice versa. Ferrer-i-Carbonell (2005) found, inter alia, that income of the reference group is about as important for individual happiness as one's own income, where the larger one's income is as compared with the reference group's, the happier this individual is. Moreover, this comparison is asymmetric and mainly upwards. Luttmer (2005: 963) matched empirical data on individual income and SWB with the local average of income and found that self-reported happiness is negatively affected by the higher earnings of neighbours. The author says that "people 
have utility functions that depend on relative consumption in addition to absolute consumption". On the other hand, there are studies not supporting the importance of relative income, for example, Diener et al. (1993). Still, such studies seem to be rather exceptional. Following the idea of Clark et al. (2008) that comparison with others and one's past play the largest roles, we made two predictions for research question 2, which serve as working hypotheses (for happiness and satisfaction separately):

2a: People in central Europe evaluating their current financial situation as better compared to most people in the country are on average happier than those evaluating it as worse.

2b: People in central Europe evaluating their current financial situation as better compared to most people in the country are on average more satisfied with their lives than those evaluating it as worse.

3a: People in central Europe evaluating their current financial situation as better compared to their own financial situation 12 months ago are on average happier than those evaluating it as worse.

3b: People in central Europe evaluating their current financial situation as better compared to their own financial situation 12 months ago are on average more satisfied with their lives than those evaluating it as worse.

Headey and Wooden (2004: 17) remarked that the variables most frequently examined were limited to income and proposed that a household's wealth (net worth) "appears to matter at least as much as income", because it provides economic security, which many people value highly. In a similar way, Christoph (2010) talks about the material situation. Following Ringen (1988), he treats income together with savings, assets and other financial measures as indirect measures, because they are "merely a proxy for the living standard actually achieved". (Christoph 2010: 481)

There is a simple idea behind it that it is not the income itself, which makes people happy. What makes them happy is the consumption of goods and services they acquire for the money they earn. In this view, consumption and living standards may be perceived as mediators in the chain between income and SWB. Adapted from Andress and Lipsmeier (2001), Christoph (2010) distinguishes among three approaches to measuring the material situation: a resource approach, a consumption approach, and a standard-of-living approach. The resource approach uses indirect variables such as income, wealth, etc.; the consumption approach relies on data regarding expenditures (direct measures); and the standard-of-living approach uses measures such as items owned, activities pursued, etc. Still, the research focused on the association of SWB with measures of consumption and resources is much scarcer.

It may be better to look at what people actually could not consume even if they would like to, instead of their actual consumption. While individual 
consumption seems to be important for understanding SWB, studying what people could not consume may bring another piece of knowledge about SWB too. A situation where one lacks goods or activities which are commonly regarded as standard is called deprivation, and related measures are called deprivation indices. (Christoph 2010) The deprivation indices were first pioneered by Peter Townsend (Townsend 1979; Townsend et al. 1986) for measuring inequalities and Carstairs and Morris (1989) in England for explaining differences in mortality. Since then, the deprivation indices have been common in poverty research, but they have scarcely been used in happiness research.

Four more working hypotheses (in two versions each) may be derived from the idea that living conditions and deprivation may play a role in terms of SWB. They are the predicted answers to the third research question.

4a: People in central Europe who are able to make ends meet easily are on average happier than those making it with difficulty.

4b: People in central Europe who are able to make ends meet easily are on average more satisfied with their lives than those making it with difficulty.

5a: People in central Europe who can afford things if they would like to get them are on average happier than those who cannot.

5b: People in central Europe who can afford things if they would like to get them are on average more satisfied with their lives than those who cannot.

6a: People in central Europe who are able to pay bills as scheduled are on average happier than those who are unable to.

6b: People in central Europe who are able to pay bills as scheduled are on average more satisfied with their lives than those who are unable to.

7a: People in central Europe who do not have problems with housing are on average happier than those who do.

7b: People in central Europe who do not have problems with housing are on average more satisfied with their lives than those who do.

SWB and its economic connotations are addressed in Czech and Slovak discourse too, whereas psychologists, sociologists as well as economists focuse on it. Kebza and Šolcová (2003) provided an analysis of SWB predominantly from a psychological point of view, whereas Heřmanová (2012) summarised the approaches and main theoretical models of quality of life (QOL) and noted that research on QOL is currently focused mainly on its subjective aspects, and presented models in which subjectively perceived well-being is embedded. Increased importance of subjective perception and evaluation of one's own life in QOL research was also noted by Hamplová (2006). In her earlier study Hamplová (2004) examined the influence of socio-demographic factors on satisfaction, but the association with income and wealth were not in the scope of that work. Večerník and Mysíková (2014) compared the influence of job 
satisfaction on SWB between eastern and western European countries. Večerník (2014) investigated the micro- and macro-economic aspects of SWB in six central European countries and identified, inter alia, that the effect of household income on satisfaction is rather weak, although statistically significant. Finally, based on the data of EU-SILC for the Czech Republic, Mysíková and Večerník (2016) found the relationship between job and life satisfaction, whereas the influence of compensation for job dissatisfaction on an employee's satisfaction with life outside of work, and vice versa, is weak. They also found that an above-median income secures more than twice the likelihood of avoiding dissatisfaction and reaching above-average satisfaction. Still, the highest job satisfaction is not necessarily ensured by an above-median income from that job. A recent study by Fialová and Štika (2015) assesses well-being in the Czech Republic and neighbouring countries using various established measures including the Human Development Index, which has a component of income (authors concluded that the current well-being in the Czech Republic is moderate among the OECD countries). Comprehensive insight into the relationships between economic theory and happiness was provided by Mlčoch (2007). The author concluded that the relationship between economic prosperity and happiness exists, but there is no simple causality from economic growth to greater happiness. On the other hand, happiness can cause economic prosperity as a by-product.

\section{Method}

This research is based on empirical data from the European Quality of Life Study (hereinafter referred as "EQLS") carried out by the European Foundation for the Improvement of Living and Working Conditions - Eurofound (Eurofound 2018a) in the entire EU and 5 candidate countries. The data from the fourth wave of the survey is used for the analysis. Only the association of SWB with a household's financial situation in comparison with most people in the country is based on the data of the third wave of EQLS, as the corresponding question is not included in the fourth wave. The data of the fourth wave of the survey was collected from September 2016 to February 2017 in central Europe, whereas the third-wave survey was conducted from September 2011 to December 2012. The fourth wave has been the latest completed edition of EQLS.

The statistical population of the study included all persons aged 18 and over residing in the country. A stratified, clustered, multi-stage sample design using random probability sampling procedures at all stages of sample selection was used. The sample was stratified according to NUTS2 regions and level of urbanisation, and clustered geographically on Primary Sampling Units. The EQLS samples can hence be considered representative of the total statistical 
population to be covered in each surveyed country. A total sample size of 4,084 respondents was achieved in all four central European countries in the fourth wave (1,014 in the Czech Republic, 1,042 in Hungary, 1,009 in Poland and 1,019 Slovakia). There was only one interview per household held where the adult household member with the next upcoming birthday was taken as the eligible respondent. More details on the sampling and data processing are available in the EQLS Technical and Fieldwork Report. (Eurofound 2018b)

SWB is measured using happiness and satisfaction in this study. Hence two sets of tests are performed in order to examine the relation of SWB with a particular independent variable. The EQLS question of happiness is formulated in the following way: "Taking all things together on a scale of 1 to 10, how happy would you say you are?" Code 1 means very unhappy and 10 means very happy on the scale. Similarly, the question of overall satisfaction is: "All things considered, how satisfied would you say you are with your life these days?" Again the scale of 1 to 10 is given, where 1 means very dissatisfied, and 10 means very satisfied ${ }^{4}$.

Household income is the figure people often do not want to declare. Out of the 4,084 EQLS respondents from examined countries, only 2,926 stated their income. The EQLS respondents were asked either exact or estimated total net income per month from all sources of all members of the household 5 . Equivalised household income based on purchasing power parity euros is used for the analysis to obtain the comparable figures. ${ }^{6}$. The equivalised income is provided within the EQLS dataset. The respondents neither stating nor estimating their income are excluded from this test of the relationship between SWB and level of income. The sample of 2,926 respondents stating their household income is divided into quartiles based on income level (all respondents having declared their income also stated both their level of satisfaction and that of happiness).

The relative standard derived from comparison with others is approximated with the EQLS question: "Could you please evaluate the financial situation of your household? In comparison to most people in your country would you say it is much worse, somewhat worse, neither worse nor better, somewhat better or much better?" It was a subjective evaluation of other people's financial situation being compared to a subjective evaluation of one's own current financial situation rather than an objective investigation of conditions. This variable had to be taken from the third survey of EQLS carried out in 2011 -

\footnotetext{
4 The questions on life satisfaction (question 4) and happiness (question 5) were asked one after the other at the very beginning of the interview. The questions on the household's material situation follow later during the interview.

5 Only one interview per household was held.

${ }^{6}$ The income quartiles are the same across all four examined countries; they are not constructed separately for each country. The income is equivalised in order to take the household composition into consideration.
} 
2012, because the fourth survey contained no questions on evaluating one's own financial situation as compared to other people in the country. A total of 5,114 out of the 5,298 EQLS respondents from the four examined countries answered the above-mentioned survey question as well as both questions on SWB.

The relative standard derived from comparison with one's own past is approximated with the EQLS question: "When you compare the financial situation of your household 12 months ago and now, would you say it has become better, worse or remained the same?" Similar to the previous case, it is about the subjective evaluation rather than the objective condition. 4,035 out of the 4,084 EQLS respondents answered the question as well as the questions on SWB.

There is a single question available for investigating whether income is sufficient to cover each household's necessary expenditures: "Thinking of your household's total monthly income: is your household able to make ends meet very easily, easily, fairly easily, with some difficulty, with difficulty or with great difficulty?" Again, the economic strain is evaluated subjectively: it has little to do with the objective situation of a respondent. The complete dataset of 3,993 respondents was analysed.

The EQLS question related to the ability to afford the selected items has six sub-questions. Respondents are asked whether their household can afford six either popular or necessary things if they would like to get them ${ }^{7}$. There are six binary variables (yes, household can afford, no, household cannot afford ${ }^{8}$ ) as a result. For the purpose of this study, these six variables are transformed into a single binary variable, where one group of respondents can afford all six things, and the other group cannot afford one to six of them. Results are excluded for 287 respondents who refused to answer either a question on the affordability of material goods (any single one out of the six) or questions on SWB. Unlike the previous cases, this variable, as well as the next two, have a more objective nature. There are hence 3,797 remaining answers to be analysed.

The question on financial problems, that is, ability to pay household bills as scheduled in the past 12 months, is designed in a similar way and has five subquestions ${ }^{9}$. These questions are all on regular monthly payments that most people need to pay. Five binary variables (able, unable) are transformed the

\footnotetext{
${ }^{7}$ Keeping home adequately warm; paying for a week's holiday away from home; replacing worn-out furniture; a meal with meat, chicken fish every second day (if desired); buying new, rather than second-hand, clothes; and having friends or family for a drink or meal at least once a month.

8 There are neither the option "We have the item" nor the option "We do not want/need this item at the moment".

9 Payments for housing (rent, mortgage), utility bills (electricity, water, etc.), consumer loans (including credit card overdrafts to buy electrical appliances, a car, furniture, etc.), bills for connection (telephone, mobile and internet) and informal loans (from friends and relatives). The respondents with neither consumer nor informal loans are asked in the same way as the others.
} 
same way as in the previous case into a single binary variable, where one group contains only respondents able to pay all the bills as scheduled whereas the second group contains respondents unable to pay up to five types of the abovelisted bills. Again, respondents having refused to answer either the whole set of four sub-questions on bill payment ability or questions on SWB are excluded from this part of the analysis. Hence there are 3,419 remaining ones to be analysed.

Similarly, there are EQLS questions dealing with respondent's housing defects. There are six sub-questions on six types of common problems with housing ${ }^{10}$. Again, they are transformed into a single binary variable where one group of respondents has no problems with their housing, and the other group has up to six problems with it. 26 respondents who were unable to answer either one or more questions on their housing or questions on SWB are excluded from this part of our analysis. There are 4,058 remaining.

With respect to the nature of the tested variables, t-tests or single factor ANOVA together with post hoc comparison techniques are used to compare the mean happiness and satisfaction among the groups. A significance level of 0.05 is used in all tests. The common assumptions of the tests, such as independence of cases, are considered to be fully satisfied because of the EQLS sample selection method. The normality assumption cannot be satisfied by definition for Likert-type ordinal scales used in this paper. Still, such scales are often treated as continuous variables, and the normal theory statistics can still be used for them. Violating the normality does not make the results of parametric tests invalid in many situations (Urdan 2016), especially for the large samples (Saunders et al. 2009), which is true in our case. Homogeneities of variances are tested statistically using Bartlett's test, and the results are provided in Appendix 1. The Bartlett's tests show that the null hypotheses of equal variances across groups cannot be supported for most factors. As the assumption of homogeneity of variances seems to be violated in most cases, Welch t-test and Welch ANOVA for unequal variances are used instead of the classic tests throughout the whole analysis ${ }^{11}$. In addition, Spearman's rank correlation coefficient (Spearman's rho) is calculated to understand better the relationship between the studied phenomena.

\footnotetext{
${ }^{10}$ Shortage of space; rot in windows, doors or floors; damp or leaks in walls or roof; lack of indoor flushing toilet; lack of bath or shower and lack of facilities (heating or cooling) to keep a comfortable temperature at home.

${ }^{11}$ Both Welch t-test and Welch ANOVA are the parametric tests (they are based on the specified distribution). Alternative using of non-parametric tests such as Kruskal-Wallis Test would yield qualitatively the same results.
} 


\section{Results and discussion}

To introduce the results section, the distribution of both happiness and life satisfaction as well as basic description based on the demographic characteristics of age and gender is provided.

Table 1: Happiness and life satisfaction - distribution.

\begin{tabular}{lrrrrrrrrrrrrrrr}
\hline $\begin{array}{l}\text { Variable } \\
\text { of SWB }\end{array}$ & $\mathbf{1}$ & $\mathbf{2}$ & $\mathbf{3}$ & $\mathbf{4}$ & $\mathbf{5}$ & $\mathbf{6}$ & $\mathbf{7}$ & $\mathbf{8}$ & $\mathbf{9}$ & $\mathbf{1 0}$ & $\mathbf{9 8}$ & $\mathbf{9 9}$ & Total \\
\cline { 2 - 13 } & 56 & 61 & 130 & 159 & 669 & 509 & 734 & 845 & 412 & 493 & 11 & 5 & $\mathbf{4 0 8 4}$ \\
\hline Happiness & 112 & 74 & 191 & 196 & 751 & 538 & 756 & 756 & 329 & 369 & 8 & 4 & $\mathbf{4 0 8 4}$ \\
\hline
\end{tabular}

Table 2: Happiness and life satisfaction per age and gender

\begin{tabular}{lcccccccc}
\hline & Male & Female & $18-24$ & $25-34$ & $35-49$ & $50-65$ & $65+$ & Total \\
\hline CZ & 447 & 567 & 51 & 143 & 284 & 278 & 258 & $\mathbf{1 0 1 4}$ \\
HU & 413 & 629 & 50 & 122 & 251 & 283 & 336 & $\mathbf{1 0 4 2}$ \\
PL & 387 & 622 & 75 & 145 & 215 & 335 & 239 & $\mathbf{1 0 0 9}$ \\
SK & 408 & 611 & 40 & 116 & 228 & 356 & 279 & $\mathbf{1 0 1 9}$ \\
& $\mathbf{1 6 5 5}$ & $\mathbf{2 4 2 9}$ & $\mathbf{2 1 6}$ & $\mathbf{5 2 6}$ & $\mathbf{9 7 8}$ & $\mathbf{1 2 5 2}$ & $\mathbf{1 1 1 2}$ & $\mathbf{4 0 8 4}$ \\
\hline
\end{tabular}

Table 3: Happiness and income - statistics and ANOVA

\begin{tabular}{|c|c|c|c|c|c|c|c|c|c|c|c|c|c|c|c|}
\hline \multirow{2}{*}{ Narrative } & \multicolumn{3}{|c|}{ Czech Republic } & \multicolumn{3}{|c|}{ Hungary } & \multicolumn{3}{|c|}{ Poland } & \multicolumn{3}{|c|}{ Slovakia } & \multicolumn{3}{|c|}{ ALL } \\
\hline & $\mathbf{N}$ & MEAN & VAR & $\mathbf{N}$ & MEAN & VAR & $\mathbf{N}$ & MEAN & VAR & $\mathbf{N}$ & MEAN & VAR & $\mathbf{N}$ & MEAN & VAR \\
\hline 1 First quartile & 80 & 6.09 & 4.08 & 253 & 6.14 & 4.82 & 216 & 6.81 & 5.18 & 182 & 6.00 & 5.31 & 731 & 6.30 & 5.06 \\
\hline 2 Second quartile & 163 & 6.22 & 3.00 & 197 & 6.82 & 4.12 & 164 & 6.91 & 5.22 & 208 & 6.66 & 4.07 & 732 & 6.66 & 4.15 \\
\hline 3 Third quartile & 226 & 6.89 & 3.79 & 151 & 7.17 & 3.43 & 155 & 7.81 & 4.27 & 204 & 7.22 & 2.77 & 736 & 7.23 & 3.63 \\
\hline 4 Fourth quartile & 216 & 6.91 & 3.11 & 158 & 7.04 & 4.21 & 191 & 7.81 & 3.74 & 162 & 7.28 & 4.75 & 727 & 7.26 & 3.99 \\
\hline All groups & 685 & 6.65 & 3.53 & 759 & 6.71 & 4.39 & 726 & 7.31 & 4.83 & 756 & 6.78 & 4.40 & 2926 & 6.86 & 4.37 \\
\hline Welch F & & 8.13 & & & 10.20 & & & 12.23 & & & 14.14 & & & 36.13 & \\
\hline DF & & 280 & & & 396 & & & 389 & & & 402 & & & 1621 & \\
\hline $\mathrm{p}$ & & 0.000 & & & 0.000 & & & 0.000 & & & 0.000 & & & 0.000 & \\
\hline Spearman's $\rho$ & & 0.174 & & & 0.192 & & & 0.203 & & & 0.229 & & & 0.186 & \\
\hline
\end{tabular}

Source: Author's own research based on Eurofound data.

As already discussed the ordinal Likert-type scales cannot be normally distributed by the definition. The distributions seem to lack the symmetry as the respondents tend to evaluate their SWB rather positively (it is negatively 
skewed). The Tables 3 and 4 show the basic statistics of both happiness and life satisfaction by income quartiles for all four examined countries together with the results of Welch ANOVA.

Table 4: Life satisfaction and income - statistics and ANOVA

\begin{tabular}{|c|c|c|c|c|c|c|c|c|c|c|c|c|c|c|c|c|}
\hline \multirow{2}{*}{ \# } & \multirow{2}{*}{ Narrative } & \multicolumn{3}{|c|}{ Czech Republic } & \multicolumn{3}{|c|}{ Hungary } & \multicolumn{3}{|c|}{ Poland } & \multicolumn{3}{|c|}{ Slovakia } & \multicolumn{3}{|c|}{ ALL } \\
\hline & & $\mathbf{N}$ & MEAN & VAR & $\mathbf{N}$ & MEAN & VAR & $\mathbf{N}$ & MEAN & VAR & $\mathbf{N}$ & MEAN & VAR & $\mathbf{N}$ & MEAN & VAR \\
\hline 1 & First quartile & 80 & 5.40 & 5.21 & 253 & 5.67 & 5.88 & 216 & 6.32 & 5.00 & 182 & 5.36 & 5.65 & 731 & 5.76 & 5.61 \\
\hline 2 & Second quartile & 163 & 5.97 & 3.50 & 197 & 6.49 & 3.82 & 164 & 6.48 & 5.20 & 208 & 6.18 & 4.50 & 732 & 6.28 & 4.28 \\
\hline 3 & Third quartile & 226 & 6.72 & 4.18 & 151 & 6.94 & 3.63 & 155 & 7.66 & 3.91 & 204 & 6.52 & 3.95 & 736 & 6.91 & 4.10 \\
\hline 4 & Fourth quartile & 216 & 6.82 & 3.05 & 158 & 6.78 & 3.82 & 191 & 7.58 & 4.38 & 162 & 6.81 & 5.12 & 727 & 7.01 & 4.13 \\
\hline & All groups & 685 & 6.42 & 4.01 & 759 & 6.37 & 4.72 & 726 & 6.97 & 5.01 & 756 & 6.21 & 5.02 & 2926 & 6.49 & 4.78 \\
\hline & Welch F & & 13.75 & & & 13.47 & & & 20.01 & & & 13.15 & & & 51.43 & \\
\hline & $\mathrm{DF}$ & & 275 & & & 400 & & & 391 & & & 406 & & & 1621 & \\
\hline & $\mathrm{p}$ & & 0.000 & & & 0.000 & & & 0.000 & & & 0.000 & & & 0.000 & \\
\hline & Spearman's $\rho$ & & 0.229 & & & 0.211 & & & 0.262 & & & 0.225 & & & 0.224 & \\
\hline
\end{tabular}

Source: Author's own research based on Eurofound data.

In summary, the mean happiness rises from quartile to quartile in both the Czech Republic and Slovakia, while a decrease appeared between the third and fourth quartiles in Hungary (both happiness and life satisfaction) and Poland (happiness is stable, and satisfaction slightly decreases). The results of Welch ANOVA showed that the null hypotheses of equal means could be rejected on the selected significance level in the case of all examined countries (separately as well as together) for both happiness and satisfaction. To understand exactly where the differences occur, the results of the post hoc analyses are shown below. The letter "Y" stands for a significant difference between the groups in a row. The complete results of the post hoc tests made in this Chapter are presented in Appendix 2.

For the purpose of evaluating the differences between the low- and highincome groups, the first and second quartiles are considered low-income, while the third and fourth are considered high-income. The comparison of the first and second quartiles, as well as the third and fourth ones, could be ignored whereas other pairs are relevant.

The null hypothesis of equal happiness between the second and third quartiles, as well as between the second and fourth quartiles, can be accepted in the case of Hungary. In this country the mean happiness rises most between the first and second quartiles, then it slows down sharply and starts fading between the third and fourth quartiles. The theoretical curve linking the means of 
happiness in the chart is concave, where the rise of mean happiness between the second and third quartiles is not statistically significant. We hence cannot accept Hypothesis 1a that high-income people are on average happier than people in low-income groups in Hungary. The Hypothesis can be accepted for all other examined countries of the Czech Republic, Poland and Slovakia as the mean happiness of people in the high-income groups (the third and fourth quartiles) is significantly higher than in the low-income groups (the first and second quartiles). This Hypothesis can also be accepted in the case of taking all the countries together.

Table 5: SWB and income - results of post hoc testing

\begin{tabular}{|c|c|c|c|c|c|c|c|c|c|c|c|}
\hline \multirow{2}{*}{\multicolumn{2}{|c|}{ Quartiles }} & \multicolumn{5}{|c|}{ Happiness } & \multicolumn{5}{|c|}{ Life satisfaction } \\
\hline & & \multirow{2}{*}{$\begin{array}{c}\mathbf{C Z} \\
\mathrm{N}\end{array}$} & \multirow{2}{*}{$\frac{\mathbf{H U}}{\mathrm{Y}}$} & \multirow{2}{*}{$\frac{\text { PL }}{\mathbf{N}}$} & \multirow{2}{*}{$\frac{\text { SK }}{\mathrm{Y}}$} & \multirow{2}{*}{$\frac{\text { ALL }}{\mathrm{Y}}$} & \multirow{2}{*}{$\frac{\mathrm{CZ}}{\mathrm{N}}$} & \multirow{2}{*}{$\begin{array}{c}\text { HU } \\
\mathrm{Y}\end{array}$} & \multirow{2}{*}{$\frac{\mathbf{P L}}{\mathrm{N}}$} & \multirow{2}{*}{$\frac{\text { SK }}{\mathrm{Y}}$} & \multirow{2}{*}{$\frac{\mathbf{A L L}}{\mathrm{Y}}$} \\
\hline 1 & 2 & & & & & & & & & & \\
\hline 1 & 3 & $\mathrm{Y}$ & $\mathrm{Y}$ & $\mathrm{Y}$ & $\mathrm{Y}$ & $\mathrm{Y}$ & $\mathrm{Y}$ & $\mathrm{Y}$ & $\mathrm{Y}$ & $\mathrm{Y}$ & $\mathrm{Y}$ \\
\hline 1 & 4 & $\mathrm{Y}$ & $\mathrm{Y}$ & $\mathrm{Y}$ & $\mathrm{Y}$ & $\mathrm{Y}$ & $\mathrm{Y}$ & $\mathrm{Y}$ & $\mathrm{Y}$ & Y & $\mathrm{Y}$ \\
\hline 2 & 3 & $\mathrm{Y}$ & $\mathbf{N}$ & $\mathrm{Y}$ & $\mathrm{Y}$ & $\mathrm{Y}$ & $\mathrm{Y}$ & $\mathrm{Y}$ & Y & $\mathbf{N}$ & $\mathrm{Y}$ \\
\hline 2 & 4 & Y & $\mathbf{N}$ & $\mathrm{Y}$ & $\mathrm{Y}$ & $\mathrm{Y}$ & $\mathrm{Y}$ & $\mathbf{N}$ & Y & $\mathrm{Y}$ & $\mathrm{Y}$ \\
\hline 3 & 4 & $\mathbf{N}$ & $\mathbf{N}$ & $\mathbf{N}$ & $\mathbf{N}$ & $\mathbf{N}$ & $\mathbf{N}$ & $\mathbf{N}$ & $\mathbf{N}$ & $\mathbf{N}$ & $\mathbf{N}$ \\
\hline
\end{tabular}

Source: Author's own research based on Eurofound data.

In the case of satisfaction, the differences are statistically insignificant between the second and fourth quartiles in Hungary and the second and third quartiles in Slovakia. Again, the theoretical curve linking the means of satisfaction in the chart looks concave in Hungary, decreasing between the third and fourth quartiles. Hypothesis $1 \mathrm{~b}$ cannot be supported for the two countries, and it can be concluded that people in the high-income groups are not on average more satisfied with their lives than those in low-income groups in Hungary and Slovakia. On the other hand, Hypothesis $1 \mathrm{~b}$ can be supported for the other two countries (the Czech Republic and Poland) as well as for central Europe as a whole.

The observed difference in evaluation of happiness between the first and fourth income quartiles is on average 0.96 on a 10-point scale for all examined countries together (0.82 in the Czech Republic, 0.90 in Hungary, 1.00 in Poland and 1,28 in Slovakia). Slightly higher differences can be observed in case of life satisfaction (1.42 in the Czech Republic, 1.11 in Hungary, 1.26 in Poland, 1.45 in Slovakia and 1.25 for all together). It is not that much, considering that the equivalised monthly income of respondents in the first 
income quartile is up to EUR 648, whereas the fourth quartile starts at EUR 1,297 (almost exactly twice). The association between SWB and income in absolute terms does not seem to be very strong on average. Still, we cannot say much about people with very high income as they are omitted from the study. It is also remarkable that the differences between the third and fourth quartiles are insignificant in each country in terms of both happiness and life satisfaction. This might indicate that the association with both happiness and life satisfaction seems to be weakening as the income increases. Such a conclusion is in accordance with the reviews provided by Dolan et al. (2008), and Diener and Ryan (2009).

The two other variables are approximations of relative income. Again the basic statistics of both happiness and life satisfaction by the defined groups for all four examined countries together with the results of Welch ANOVA follow.

Table 6: Happiness and relative income comparing to others - statistics and ANOVA

\begin{tabular}{|c|c|c|c|c|c|c|c|c|c|c|c|c|c|c|c|}
\hline \multirow{2}{*}{ Narrative } & \multicolumn{3}{|c|}{ Czech Republic } & \multicolumn{3}{|c|}{ Hungary } & \multicolumn{3}{|c|}{ Poland } & \multicolumn{3}{|c|}{ Slovakia } & \multicolumn{3}{|c|}{ ALL } \\
\hline & $\mathbf{N}$ & MEAN & VAR & $\mathbf{N}$ & MEAN & VAR & $\mathbf{N}$ & MEAN & VAR & $\mathbf{N}$ & MEAN & VAR & $\mathbf{N}$ & MEAN & VAR \\
\hline 1 Much worse & 49 & 5.53 & 3.50 & 69 & 5.65 & 7.55 & 164 & 5.60 & 5.69 & 113 & 5.28 & 4.69 & 395 & 5.51 & $\overline{5.44}$ \\
\hline 2 Somewhat worse & 238 & 6.34 & 3.26 & 218 & 6.18 & 4.80 & 407 & 6.56 & 4.22 & 237 & 6.23 & 3.28 & 1100 & 6.36 & 3.94 \\
\hline 3 Neither w. nor b. & 500 & 7.39 & 2.42 & 543 & 7.19 & 3.58 & 1229 & 7.49 & 2.94 & 493 & 7.27 & 2.63 & 2765 & 7.37 & 2.93 \\
\hline 4 Somewhat better & 167 & 7.61 & 2.34 & 130 & 7.88 & 2.86 & 308 & 7.99 & 2.70 & 115 & 7.72 & 2.38 & 720 & 7.84 & 2.61 \\
\hline 5 Much better & 30 & 8.00 & 2.69 & 16 & 8.81 & 3.36 & 78 & 8.64 & 1.71 & 10 & 6.70 & 6.23 & 134 & 8.37 & 2.69 \\
\hline All groups & 984 & 7.10 & 3.04 & 976 & 6.97 & 4.47 & 2186 & 7.29 & 3.77 & 968 & 6.83 & 3.58 & 5114 & 7.10 & 3.76 \\
\hline Welch F & & 29.49 & & & 24.64 & & & 68.04 & & & 36.88 & & & 152.40 & \\
\hline DF & & 136 & & & 92 & & & 376 & & & 63 & & & 726 & \\
\hline $\mathrm{p}$ & & 0.000 & & & 0.000 & & & 0.000 & & & 0.000 & & & 0.000 & \\
\hline Spearman's $\rho$ & & 0.321 & & & 0.311 & & & 0.322 & & & 0.375 & & & 0.334 & \\
\hline
\end{tabular}

Source: Author's own research based on Eurofound data

Both happiness and satisfaction rise pretty consistently from group to group with only a few exceptions. In the Czech Republic, people evaluating their financial situation as much better report slightly lower satisfaction with their lives than people reporting a somewhat better situation; still, the difference is statistically insignificant. There are remarkable falls in the reported happiness and satisfaction between the 'somewhat better' and 'much better' groups in Slovakia. However it should be noted that there are only 10 respondents evaluating their financial situation much better comparing to most people in Slovakia. 
Table 7: Life satisfaction and relative income comparing to others statistics and ANOVA

\begin{tabular}{|c|c|c|c|c|c|c|c|c|c|c|c|c|c|c|c|c|}
\hline \multirow{2}{*}{$\#$} & \multirow{2}{*}{ \# Narrative } & \multicolumn{3}{|c|}{ Czech Republic } & \multicolumn{3}{|c|}{ Hungary } & \multicolumn{3}{|c|}{ Poland } & \multicolumn{3}{|c|}{ Slovakia } & \multicolumn{3}{|c|}{ ALL } \\
\hline & & $\mathbf{N}$ & MEAN & VAR & $\mathbf{N}$ & MEAN & VAR & $\mathbf{N}$ & MEAN & VAR & $\mathbf{N}$ & MEAN & VAR & $\mathbf{N}$ & MEAN & VAR \\
\hline 1 & Much worse & 49 & 4.80 & 5.08 & 69 & 4.13 & 6.14 & 164 & 5.01 & 6.63 & 113 & 4.31 & 4.32 & 395 & 4.63 & 5.79 \\
\hline 2 & $\begin{array}{l}\text { Somewhat } \\
\text { worse }\end{array}$ & 238 & 5.44 & 4.86 & 218 & 4.87 & 5.01 & 407 & 6.14 & 4.77 & 237 & 5.76 & 4.13 & $\begin{array}{c}1 \\
100\end{array}$ & 5.66 & 4.91 \\
\hline 3 & $\begin{array}{l}\text { Neither w. } \\
\text { nor b. }\end{array}$ & 500 & 6.74 & 3.47 & 543 & 6.19 & 4.45 & $\begin{array}{c}1 \\
229\end{array}$ & 7.33 & 3.31 & 493 & 6.77 & 3.19 & $\begin{array}{c}2 \\
765\end{array}$ & 6.90 & 3.73 \\
\hline 4 & $\begin{array}{l}\text { Somewhat } \\
\text { better }\end{array}$ & 167 & 7.26 & 3.35 & 130 & 7.03 & 3.77 & 308 & 7.74 & 3.14 & 115 & 7.56 & 2.58 & 720 & 7.47 & 3.28 \\
\hline \multirow{6}{*}{5} & Much better & 30 & 7.20 & 5.96 & 16 & 7.88 & 2.38 & 78 & 8.73 & 1.29 & 10 & 5.80 & 6.84 & 134 & 8.07 & 3.60 \\
\hline & All groups & 984 & 6.43 & 4.48 & 976 & 5.89 & 5.29 & 2186 & 7.04 & 4.41 & 968 & 6.32 & 4.34 & 5114 & 6.57 & 4.77 \\
\hline & Welch F & & 30.16 & & & 39.14 & & & 96.06 & & & 52.89 & & & 191.14 & \\
\hline & $\mathrm{DF}$ & & 134 & & & 95 & & & 387 & & & 63 & & & 726 & \\
\hline & $\mathrm{p}$ & & 0.000 & & & 0.000 & & & 0.000 & & & 0.000 & & & 0.000 & \\
\hline & Spearman's $\rho$ & & 0.339 & & & 0.372 & & & 0.346 & & & 0.407 & & & 0.363 & \\
\hline
\end{tabular}

Source: Author's own research based on Eurofound data.

In this case, the results of Welch ANOVA also showed that the null hypotheses of equal means could be rejected on the selected significance level in the case of all examined countries (separately as well as together) for both happiness and satisfaction. The next Table shows the results of subsequent multiple comparisons.

Table 8: SWB and relative income comparing to others - results of post hoc testing

\begin{tabular}{|c|c|c|c|c|c|c|c|c|c|c|c|}
\hline \multirow{2}{*}{ Group1 } & \multirow{2}{*}{ Group2 } & \multicolumn{5}{|c|}{ Happiness } & \multicolumn{5}{|c|}{ Life satisfaction } \\
\hline & & $\mathbf{C Z}$ & HU & PL & SK & $\mathbf{A L L}$ & $\mathbf{C Z}$ & HU & PL & SK & ALL \\
\hline 1 Much worse & 2 Somewhat worse & $\mathrm{Y}$ & $\mathbf{N}$ & $\mathrm{Y}$ & $\mathrm{Y}$ & $\mathrm{Y}$ & $\mathbf{N}$ & $\mathrm{Y}$ & $\mathrm{Y}$ & $\mathrm{Y}$ & $\mathrm{Y}$ \\
\hline 1 Much worse & 3 Neither w. nor b. & $\mathrm{Y}$ & $\mathrm{Y}$ & $\mathrm{Y}$ & $\mathrm{Y}$ & $\mathrm{Y}$ & $\mathrm{Y}$ & $\mathrm{Y}$ & $\mathrm{Y}$ & $\mathrm{Y}$ & $\mathrm{Y}$ \\
\hline 1 Much worse & 4 Somewhat better & $\mathrm{Y}$ & $\mathrm{Y}$ & $\mathrm{Y}$ & $\mathrm{Y}$ & $\mathrm{Y}$ & $\mathrm{Y}$ & $\mathrm{Y}$ & Y & $\mathrm{Y}$ & $\mathrm{Y}$ \\
\hline 1 Much worse & 5 Much better & $\mathrm{Y}$ & $\mathrm{Y}$ & $\mathrm{Y}$ & $\mathbf{N}$ & $\mathrm{Y}$ & $\mathrm{Y}$ & $\mathrm{Y}$ & $\mathrm{Y}$ & $\mathbf{N}$ & $\mathrm{Y}$ \\
\hline 2 Somewhat worse & 3 Neither w. nor b. & $\mathrm{Y}$ & $\mathrm{Y}$ & $\mathrm{Y}$ & $\mathrm{Y}$ & $\mathrm{Y}$ & $\mathrm{Y}$ & $\mathrm{Y}$ & $\mathrm{Y}$ & $\mathrm{Y}$ & $\mathrm{Y}$ \\
\hline 2 Somewhat worse & 4 Somewhat better & $\mathrm{Y}$ & $\mathrm{Y}$ & $\mathrm{Y}$ & Y & $\mathrm{Y}$ & $\mathrm{Y}$ & $\mathrm{Y}$ & $\mathrm{Y}$ & $\mathrm{Y}$ & $\mathrm{Y}$ \\
\hline 2 Somewhat worse & 5 Much better & $\mathrm{Y}$ & $\mathrm{Y}$ & $\mathrm{Y}$ & $\mathbf{N}$ & $\mathrm{Y}$ & $\mathrm{Y}$ & $\mathrm{Y}$ & $\mathrm{Y}$ & $\mathbf{N}$ & $\mathrm{Y}$ \\
\hline 3 Neither w. nor b. & 4 Somewhat better & $\mathrm{Y}$ & Y & $\mathrm{Y}$ & $\mathrm{Y}$ & $\mathrm{Y}$ & $\mathrm{Y}$ & Y & Y & $\mathrm{Y}$ & Y \\
\hline 3 Neither w. nor b. & 5 Much better & $\mathbf{N}$ & $\mathrm{Y}$ & $\mathrm{Y}$ & $\mathbf{N}$ & $\mathrm{Y}$ & $\mathbf{N}$ & $\mathrm{Y}$ & $\mathrm{Y}$ & $\mathbf{N}$ & $\mathrm{Y}$ \\
\hline 4 Somewhat better & 5 Much better & $\mathbf{N}$ & $\mathbf{N}$ & $\mathrm{Y}$ & $\mathbf{N}$ & $\mathrm{Y}$ & $\mathbf{N}$ & $\mathbf{N}$ & $\mathrm{Y}$ & $\mathbf{N}$ & $\mathrm{Y}$ \\
\hline
\end{tabular}

Source: Author's own research based on Eurofound data. 
Only pairs with opposite meaning are the relevant ones taken into account as criteria for a decision over the given hypotheses. (The pairs with the neutral option are hence ignored too.) The null hypothesis of equal means of the opposite pairs can only be confirmed in the case of Slovakia (both happiness and life satisfaction). Slovaks evaluating their financial situation as much better comparing to most people in the country are significantly less happy and less satisfied than those evaluating them only as somewhat worse, and their happiness, as well as satisfaction, is significantly better than those reporting them as neither much worse nor somewhat worse. Therefore, Hypotheses $2 \mathrm{a}$ and $2 \mathrm{~b}$ cannot be accepted in the case of Slovakia, but can be accepted in the cases of other examined countries. In case the group of 10 respondents evaluating their income as much better comparing to most people in Slovakia was ignored, both hypotheses could be confirmed even for Slovakia. The SWB of people with high relative incomes comparing to most people in Slovakia still remains the issue to be resolved. EQLS seems to provide us with an insufficient set of data for the analysis. Thus there is room for further research.

This study may join the research stream accentuating the importance of relative income. The difference between those who evaluate their financial situation as much worse and those who evaluate it as much better is 2.86 (happiness in all examined on average) and 3.44 (satisfaction in all examined on average) on a 10-point scale, which is considerably more than in the case of income quartiles. Some research on relative income suggests that an individual with above-average income is not happier than the reference group, while SWB of a poorer individual is negatively influenced by the fact of his income being lower than that of the reference group. (Ferrer-i-Carbonell 2005) Such pattern is not confirmed by our analysis, as both happiness and satisfaction rise steadily throughout the scale of the evaluated financial situation from much worse to much better in all countries, with the discussed exception of Slovakia.

There is research suggesting that SWB may behave differently with respect to relative income in Eastern Europe comparing to Western Europe. Based on data from the European Social Survey for 19 countries, Caporale et al. (2009) discovered a different pattern in Eastern Europe countries, where the reference income impacted SWB positively ${ }^{12}$. It means a lower-than-reference income of an individual positively affected his SWB. The authors concluded that, in a stable environment, the reference income serves as a measure for comparison, while in a less stable environment (e.g., during rapid development) the reference income is a promise for one's future situation. The tunnel effect was not confirmed by our study either. From the perspective of the relationship between SWB and relative income, it seems that the four examined central

12 This pattern is called "tunnel effect". 
European countries have become rather stable and developed during the past 10 years, i.e., since the above-mentioned study was conducted.

Subjective past financial situation is another benchmark of income evaluation. Statistics and results of ANOVA are summarised in the following two Tables.

Table 9: Happiness and relative income comparing to past - statistics and ANOVA

\begin{tabular}{|c|c|c|c|c|c|c|c|c|c|c|c|c|c|c|c|c|}
\hline \multirow{2}{*}{ \# } & \multirow{2}{*}{ Narrative } & \multicolumn{3}{|c|}{ Czech Republic } & \multicolumn{3}{|c|}{ Hungary } & \multicolumn{3}{|c|}{ Poland } & \multicolumn{3}{|c|}{ Slovakia } & \multicolumn{3}{|c|}{ ALL } \\
\hline & & $\mathbf{N}$ & MEAN & VAR & $\mathbf{N}$ & MEAN & VAR & $\mathbf{N}$ & MEAN & VAR & $\mathbf{N}$ & MEAI & VAR & $\mathbf{N}$ & MEAN & VAR \\
\hline 1 & Better & 130 & 7.02 & 4.06 & 100 & 7.55 & 4.51 & 119 & 7.92 & 3.25 & 91 & 7.75 & 3.01 & 440 & 7.53 & 3.83 \\
\hline 2 & The same & 720 & 6.81 & 3.21 & 750 & 6.88 & 3.97 & 696 & 7.50 & 4.39 & 756 & 6.91 & 3.76 & 2922 & 7.02 & 3.90 \\
\hline 3 & Worse & 155 & 6.29 & 3.31 & 183 & 5.90 & 5.70 & 172 & 6.26 & 5.02 & 163 & 5.96 & 5.39 & 673 & 6.10 & 4.91 \\
\hline & All groups & 1005 & 6.76 & 3.37 & 1033 & 6.77 & 4.53 & 987 & 7.33 & 4.62 & 1010 & 6.83 & 4.15 & 4035 & 6.92 & 4.22 \\
\hline & Welch F & & 6.51 & & & 19.70 & & & 27.74 & & & 24.23 & & & 71.11 & \\
\hline & DF & & 244 & & & 213 & & & 258 & & & 196 & & & 915 & \\
\hline & $\mathrm{p}$ & & 0.000 & & & 0.000 & & & 0.000 & & & 0.000 & & & 0.000 & \\
\hline & Spearman's $\rho$ & & 0.122 & & & 0.198 & & & 0.216 & & & 0.206 & & & 0.185 & \\
\hline
\end{tabular}

Source: Author's own research based on Eurofound data.

Table 10: Life satisfaction and relative income comparing to past statistics and ANOVA

\begin{tabular}{|c|c|c|c|c|c|c|c|c|c|c|c|c|c|c|c|c|}
\hline \multirow{2}{*}{$\#$} & \multirow{2}{*}{ Narrative } & \multicolumn{3}{|c|}{ Czech Republic } & \multicolumn{3}{|c|}{ Hungary } & \multicolumn{3}{|c|}{ Poland } & \multicolumn{3}{|c|}{ Slovakia } & \multicolumn{3}{|c|}{ ALL } \\
\hline & & $\mathbf{N}$ & MEAN & VAR & $\mathbf{N}$ & MEAN & JVAR & $\mathbf{N}$ & MEAN & VAR & $\mathbf{N}$ & MEAN & JVAR & $\mathbf{N}$ & MEAI & VAR \\
\hline 1 & Better & 130 & 6.72 & 4.62 & 100 & 7.12 & 2.83 & 119 & 7.47 & 3.83 & 91 & 7.19 & 4.09 & 440 & 7.11 & 3.95 \\
\hline 2 & The same & 720 & 6.60 & 3.73 & 750 & 6.58 & 4.20 & 696 & 7.27 & 4.44 & 756 & 6.32 & 4.19 & 2922 & 6.68 & 4.26 \\
\hline \multirow{6}{*}{3} & Worse & 155 & 5.81 & 3.74 & 183 & 5.23 & 5.63 & 172 & 5.83 & 4.27 & 163 & 5.27 & 6.63 & 673 & 5.53 & 5.15 \\
\hline & All groups & 1005 & 6.50 & 3.93 & 1033 & 6.39 & 4.63 & 987 & 7.05 & 4.64 & 1010 & 6.23 & 4.81 & 4035 & 6.54 & 4.59 \\
\hline & Welch F & & 11.45 & & & 33.44 & & & 36.51 & & & 21.76 & & & 91.66 & \\
\hline & $\mathrm{DF}$ & & 245 & & & 229 & & & 256 & & & 190 & & & 924 & \\
\hline & $\mathrm{p}$ & & 0.000 & & & 0.000 & & & 0.000 & & & 0.000 & & & 0.000 & \\
\hline & Spearman's $\rho$ & & 0.138 & & & 0.239 & & & 0.234 & & & 0.210 & & & 0.205 & \\
\hline
\end{tabular}

Source: Author's own research based on Eurofound data.

In this case, people evaluating their current financial situation as better comparing to their own financial situation 12 months ago are on average happier and more satisfied with their lives than those evaluating it as the same in each examined country, whereas the latter group of people is happier and more satisfied than people evaluating their situation worse than 12 months ago in each country again. The null hypotheses of equal means must clearly be 
rejected in each country based on ANOVA tests. Results of the post hoc multiple tests are summarised below.

Table 11: SWB and relative income comparing to past - results of post hoc testing

\begin{tabular}{|c|c|c|c|c|c|c|c|c|c|c|c|}
\hline \multirow{2}{*}{ Group1 } & \multirow{2}{*}{ Group2 } & \multicolumn{5}{|c|}{ Happiness } & \multicolumn{5}{|c|}{ Life satisfaction } \\
\hline & & $\mathrm{CZ}$ & HU & PL & SK & ALL & $\mathbf{C Z}$ & HU & PL & SK & ALL \\
\hline 1 Better & 2 The same & $\mathbf{N}$ & $\mathrm{Y}$ & $\mathrm{Y}$ & $\mathrm{Y}$ & $\mathrm{Y}$ & $\mathbf{N}$ & $\mathrm{Y}$ & $\mathbf{N}$ & $\mathrm{Y}$ & $\mathrm{Y}$ \\
\hline 1 Better & 3 Worse & Y & $\mathrm{Y}$ & $\mathrm{Y}$ & $\mathrm{Y}$ & $\mathrm{Y}$ & $\mathrm{Y}$ & $\mathrm{Y}$ & $\mathrm{Y}$ & $\mathrm{Y}$ & $\mathrm{Y}$ \\
\hline 2 The same & 3 Worse & $\mathrm{Y}$ & Y & Y & Y & $\mathrm{Y}$ & $\mathrm{Y}$ & Y & Y & Y & Y \\
\hline
\end{tabular}

Source: Author's own research based on Eurofound data.

The key pair for a decision over the given hypothesis is the one comparing people evaluating the situation as better and those comparing it as worse. The "better" group has significantly higher average happiness and higher life satisfaction than the "worse" group; hence Hypotheses $3 \mathrm{a}$ and $3 \mathrm{~b}$ can be accepted for each single examined country as well as for central Europe as a whole.

Household income is one side of the balance and expenditures constitute the second side. Subjective economic strain measured by the ability to make ends meet ranks from able very easily to able with great difficulty whereas there is no neutral option. Statistics and result of ANOVA are summarised below.

Table 12: Happiness and subjective economic strain - statistics and ANOVA

\begin{tabular}{|c|c|c|c|c|c|c|c|c|c|c|c|c|c|c|c|c|}
\hline \multirow{2}{*}{$\#$} & \multirow{2}{*}{ Narrative } & \multicolumn{3}{|c|}{ Czech Republic } & \multicolumn{3}{|c|}{ Hungary } & \multicolumn{3}{|c|}{ Poland } & \multicolumn{3}{|c|}{ Slovakia } & \multicolumn{3}{|c|}{ ALL } \\
\hline & & $\mathbf{N}$ & MEAN & VAR & $\mathbf{N}$ & MEAN & VAR & $\mathbf{N}$ & MEAN & VAR & $\mathbf{N}$ & MEAN & VAR & $\mathbf{N}$ & MEAN & VAR \\
\hline 1 & Very easily & 43 & 7.19 & 4.54 & 15 & 7.27 & 6.92 & 41 & 8.66 & 3.58 & 31 & 8.87 & 2.85 & 130 & 8.06 & 4.60 \\
\hline 2 & Easily & 146 & 7.51 & 3.48 & 98 & 7.65 & 4.04 & 159 & 8.36 & 2.78 & 115 & 7.82 & 3.10 & 518 & 7.86 & 3.39 \\
\hline 3 & Fairly easily & 389 & 7.02 & 2.82 & 253 & 7.40 & 3.49 & 358 & 7.68 & 3.30 & 198 & 7.25 & 2.89 & 1198 & 7.33 & 3.18 \\
\hline 4 & $\begin{array}{l}\text { With some } \\
\text { diff. }\end{array}$ & 305 & 6.50 & 2.90 & 475 & 6.74 & 3.76 & 261 & 6.87 & 4.54 & 430 & 6.80 & 3.22 & 1471 & 6.73 & 3.57 \\
\hline 5 & $\begin{array}{l}\text { With } \\
\text { difficulty }\end{array}$ & 92 & 5.77 & 2.82 & 124 & 6.02 & 4.35 & 102 & 6.30 & 5.26 & 161 & 6.03 & 3.98 & 479 & 6.04 & 4.13 \\
\hline & $\begin{array}{l}\text { With great } \\
\text { diff. }\end{array}$ & 29 & 4.90 & 4.38 & 57 & 4.44 & 7.04 & 49 & 5.45 & 8.00 & 62 & 4.82 & 7.59 & 197 & 4.88 & 7.10 \\
\hline & All groups & 1004 & 6.76 & 3.36 & 1022 & 6.78 & 4.54 & 970 & 7.36 & 4.62 & 997 & 6.82 & 4.13 & 3993 & 6.93 & 4.22 \\
\hline & Welch F & & 18.96 & & & 20.65 & & & 27.03 & & & 29.28 & & & 89.82 & \\
\hline & DF & & 159 & & & 112 & & & 200 & & & 189 & & & 731 & \\
\hline & $\mathrm{p}$ & & 0.000 & & & 0.000 & & & 0.000 & & & 0.000 & & & 0.000 & \\
\hline & Spearman's $\rho$ & & 0.296 & & & 0.306 & & & 0.357 & & & 0.352 & & & 0.331 & \\
\hline
\end{tabular}

Source: Author's own research based on Eurofound data. 
Table 13: Life satisfaction and subjective economic strain - statistics and ANOVA

\begin{tabular}{|c|c|c|c|c|c|c|c|c|c|c|c|c|c|c|c|c|}
\hline \multirow{2}{*}{ \# } & \multirow{2}{*}{ Narrative } & \multicolumn{3}{|c|}{ Czech Republic } & \multicolumn{3}{|c|}{ Hungary } & \multicolumn{3}{|c|}{ Poland } & \multicolumn{3}{|c|}{ Slovakia } & \multicolumn{3}{|c|}{ ALL } \\
\hline & & $\mathbf{N}$ & MEAN & VAR & $\mathbf{N}$ & MEAN & VAR & $\mathbf{N}$ & MEAN & VAR & $\mathbf{N}$ & MEAN & VAR & $\mathbf{N}$ & MEAN & VAR \\
\hline 1 & Very easily & 43 & 7.53 & 3.92 & 15 & 7.60 & 6.40 & 41 & 8.68 & 3.12 & 31 & 8.13 & 5.45 & 130 & 8.05 & 4.45 \\
\hline 2 & Easily & 146 & 7.35 & 4.23 & 98 & 7.41 & 3.44 & 159 & 8.01 & 3.13 & 115 & 7.22 & 3.21 & 518 & 7.53 & 3.60 \\
\hline 3 & Fairly easily & 389 & 6.82 & 3.05 & 253 & 7.20 & 2.93 & 358 & 7.53 & 3.35 & 198 & 6.85 & 3.63 & 1198 & 7.12 & 3.30 \\
\hline 4 & $\begin{array}{l}\text { With some } \\
\text { diff. }\end{array}$ & 305 & 6.12 & 3.23 & 475 & 6.37 & 3.65 & 261 & 6.39 & 4.45 & 430 & 6.17 & 3.52 & 1471 & 6.26 & 3.67 \\
\hline 5 & $\begin{array}{l}\text { With } \\
\text { difficulty }\end{array}$ & 92 & 5.18 & 3.73 & 124 & 5.20 & 5.11 & 102 & 5.88 & 4.58 & 161 & 5.38 & 5.05 & 479 & 5.40 & 4.75 \\
\hline 6 & $\begin{array}{l}\text { With great } \\
\text { diff. }\end{array}$ & 29 & 4.38 & 4.60 & 57 & 3.67 & 5.62 & 49 & 5.29 & 6.46 & 62 & 3.87 & 6.90 & 197 & 4.24 & 6.41 \\
\hline & All groups & 100 & 6.50 & 3.92 & 1022 & 6.40 & 4.63 & 970 & 7.07 & 4.63 & 997 & 6.21 & 4.77 & 3993 & 6.54 & 4.58 \\
\hline & Welch F & & 26.40 & & & 37.67 & & & 35.25 & & & 29.12 & & & 128.37 & \\
\hline & DF & & 159 & & & 112 & & & 202 & & & 187 & & & 732 & \\
\hline & $\mathrm{p}$ & & 0.000 & & & 0.000 & & & 0.000 & & & 0.000 & & & 0.000 & \\
\hline & Spearman's $\rho$ & & 0.354 & & & 0.385 & & & 0.404 & & & 0.373 & & & 0.386 & \\
\hline
\end{tabular}

Source: Author's own research based on Eurofound data.

Table 14: SWB and ability to make ends meet - results of post hoc testing

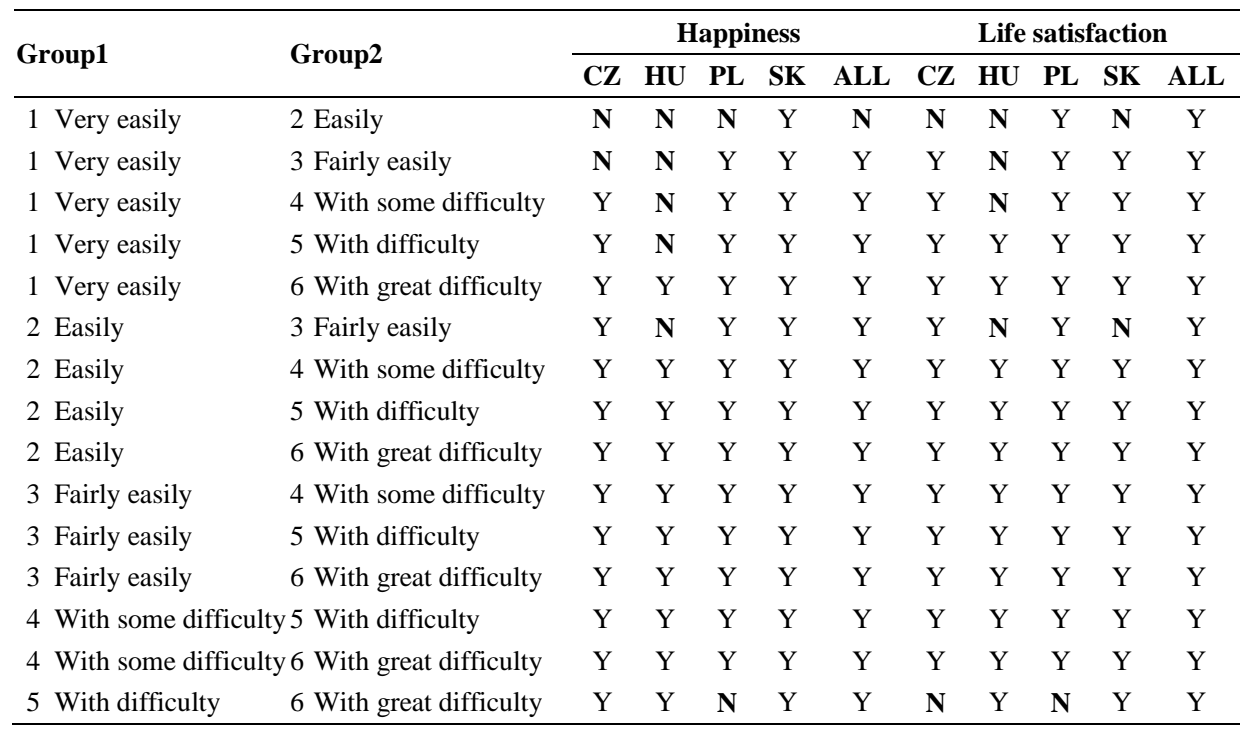

Source: Author's own research based on Eurofound data. 
It seems that the easier it is to make ends meet, the higher mean happiness and life satisfaction are in all four countries. There are two exceptions from this pattern. People making ends meet very easily are less happy than people making it only easily in the Czech Republic and in Hungary. Even so, the differences between the two groups are statistically insignificant in neither country as is clear from the Table 14 .

The criteria to decide whether to accept or reject the hypotheses on the ability to make ends meet are the same as they were in previous instances. It means the pair groups with opposite meaning are the only relevant ones. Multiple comparison tests clarify that happiness is not equal between the opposite groups in any country except Hungary, where people making ends meet very easily seem to be equally happy as those making it either with difficulty or with some difficulty. Similarly, people making ends meet very easily seem to be equally satisfied with their lives as people making it with some difficulty ${ }^{13}$. Still, Hypotheses $4 \mathrm{a}$ and $4 \mathrm{~b}$ can both be accepted for the Czech Republic, Poland and Slovakia as well as for central Europe as a whole, but not for Hungary.

In their analysis on economic characteristics and SWB Želinský et al. (2018) suggested that SWB of people living in indebted households (who can be expected to be unable to make ends meet) is lower than those living in households free of debts, but the total score is only 1 point lower in Slovakia. The capacity to face unexpected financial expenses is another important indicator used in the study. It predicts the financial stability of a household. The authors conclude that SWB of people living in financially unstable households is significantly lower (3.4 points on average) in comparison to people living in households with sufficient capacity to face financial problems. Compared to that, the differences in both happiness and satisfaction between groups of people who are able to make ends meet very easily and those making it with great difficulty were also found considerable (3.18 in the case of happiness and 3.81 in the case of life satisfaction on a 10-point scale taking all countries together) in this paper. It stresses the importance of household income relative to expenses rather than the income itself. It is suggested that subjective evaluation of economic strain is more important for SWB than objective income conditions. Such findings may be worth considering for further research.

The Tables below present the results of statistically comparing mean happiness and mean satisfaction based on the three factor variables; namely, ability to afford selected items, financial and housing problems.

13 The sample size of Hungarian respondents making ends meet very easily is only 15 . 
Table 15: Happiness and ability to afford selected items - comparing means

\begin{tabular}{|c|c|c|c|c|c|c|c|c|c|c|}
\hline & \multicolumn{2}{|c|}{ Czech Republic } & \multicolumn{2}{|c|}{ Hungary } & \multicolumn{2}{|c|}{ Poland } & \multicolumn{2}{|c|}{ Slovakia } & \multicolumn{2}{|c|}{ ALL } \\
\hline & Able & Unable & Able & Unable & Able & Unable & Able & Unable & Able & Unable \\
\hline Mean & 7.27 & 6.30 & 7.57 & 6.40 & 8.08 & 6.90 & 7.52 & 6.25 & 7.59 & 6.47 \\
\hline Variance & 3.13 & 3.17 & 3.45 & 4.63 & 3.18 & 4.80 & 3.26 & 4.22 & 3.32 & 4.31 \\
\hline Std. dev. & 1.77 & 1.78 & 1.86 & 2.15 & 1.78 & 2.19 & 1.81 & 2.05 & 1.82 & 2.08 \\
\hline $\mathrm{N}$ & 471 & 492 & 307 & 687 & 373 & 543 & 425 & 499 & 1576 & 2221 \\
\hline Mean diff. & \multicolumn{2}{|c|}{0.97} & \multicolumn{2}{|c|}{1.17} & \multicolumn{2}{|c|}{1.18} & \multicolumn{2}{|c|}{1.27} & \multicolumn{2}{|c|}{1.12} \\
\hline $\mathrm{DF}$ & \multicolumn{2}{|c|}{959.640} & \multicolumn{2}{|c|}{675.295} & \multicolumn{2}{|c|}{888.187} & \multicolumn{2}{|c|}{921.008} & \multicolumn{2}{|c|}{3628.970} \\
\hline Welch t & \multicolumn{2}{|c|}{8.489} & \multicolumn{2}{|c|}{8.738} & \multicolumn{2}{|c|}{8.957} & \multicolumn{2}{|c|}{10.031} & \multicolumn{2}{|c|}{17.637} \\
\hline $\mathrm{p}$ & \multicolumn{2}{|c|}{0.000} & \multicolumn{2}{|c|}{0.000} & \multicolumn{2}{|c|}{0.000} & \multicolumn{2}{|c|}{0.000} & \multicolumn{2}{|c|}{0.000} \\
\hline Spearman's $\rho$ & \multicolumn{2}{|c|}{0.277} & \multicolumn{2}{|c|}{0.270} & \multicolumn{2}{|c|}{0.276} & \multicolumn{2}{|c|}{0.311} & \multicolumn{2}{|c|}{0.276} \\
\hline
\end{tabular}

Source: Author's own research based on Eurofound data.

Table 16: Life satisfaction and ability to afford selected items - comparing means

\begin{tabular}{|c|c|c|c|c|c|c|c|c|c|c|}
\hline & \multicolumn{2}{|c|}{ Czech Republic } & \multicolumn{2}{|c|}{ Hungary } & \multicolumn{2}{|c|}{ Poland } & \multicolumn{2}{|c|}{ Slovakia } & \multicolumn{2}{|c|}{ ALL } \\
\hline & Able & Unable & Able & Unable & Able & Unable & Able & Unable & Able & Unable \\
\hline Mean & 7.10 & 5.93 & 7.30 & 5.97 & 7.84 & 6.58 & 6.83 & 5.65 & 7.24 & 6.04 \\
\hline Variance & 3.46 & 3.78 & 2.78 & 4.86 & 3.29 & 4.76 & 3.87 & 5.06 & 3.53 & 4.75 \\
\hline Std. dev. & 1.86 & 1.94 & 1.67 & 2.21 & 1.82 & 2.18 & 1.97 & 2.25 & 1.88 & 2.18 \\
\hline $\mathrm{N}$ & 471 & 492 & 307 & 687 & 373 & 543 & 425 & 499 & 1576 & 2221 \\
\hline Mean diff. & \multicolumn{2}{|c|}{1.17} & \multicolumn{2}{|c|}{1.33} & \multicolumn{2}{|c|}{1.26} & \multicolumn{2}{|c|}{1.18} & \multicolumn{2}{|c|}{1.20} \\
\hline $\mathrm{DF}$ & \multicolumn{2}{|c|}{961.000} & \multicolumn{2}{|c|}{763.287} & \multicolumn{2}{|c|}{880.989} & \multicolumn{2}{|c|}{921.354} & \multicolumn{2}{|c|}{3653.892} \\
\hline Welch t & \multicolumn{2}{|c|}{9.520} & \multicolumn{2}{|c|}{10.521} & \multicolumn{2}{|c|}{9.485} & \multicolumn{2}{|c|}{8.526} & \multicolumn{2}{|c|}{18.202} \\
\hline $\mathrm{p}$ & \multicolumn{2}{|c|}{0.000} & \multicolumn{2}{|c|}{0.000} & \multicolumn{2}{|c|}{0.000} & \multicolumn{2}{|c|}{0.000} & \multicolumn{2}{|c|}{0.000} \\
\hline Spearman's $\rho$ & \multicolumn{2}{|c|}{0.300} & \multicolumn{2}{|c|}{0.296} & \multicolumn{2}{|c|}{0.295} & \multicolumn{2}{|c|}{0.270} & \multicolumn{2}{|c|}{0.281} \\
\hline
\end{tabular}

Source: Author's own research based on Eurofound data.

Table 17: Happiness and financial problems - comparing means

\begin{tabular}{|c|c|c|c|c|c|c|c|c|c|c|}
\hline & \multicolumn{2}{|c|}{ Czech Republic } & \multicolumn{2}{|c|}{ Hungary } & \multicolumn{2}{|c|}{ Poland } & \multicolumn{2}{|c|}{ Slovakia } & \multicolumn{2}{|c|}{ ALL } \\
\hline & Unable & Able & Unable & Able & Unable & Able & Unable & Able & Unable & Able \\
\hline Mean & 6.21 & 6.85 & 6.06 & 6.75 & 6.42 & 7.61 & 5.62 & 6.91 & 6.14 & 7.02 \\
\hline Variance & 3.18 & 3.39 & 5.19 & 4.43 & 5.55 & 3.82 & 6.49 & 3.90 & 4.95 & 3.97 \\
\hline Std. dev. & 1.78 & 1.84 & 2.28 & 2.11 & 2.36 & 1.96 & 2.55 & 1.97 & 2.22 & 1.99 \\
\hline $\mathrm{N}$ & 115 & 819 & 142 & 688 & 113 & 674 & 58 & 810 & 428 & 2991 \\
\hline Mean diff. & \multicolumn{2}{|c|}{0.64} & \multicolumn{2}{|c|}{0.69} & \multicolumn{2}{|c|}{1.19} & \multicolumn{2}{|c|}{1.29} & \multicolumn{2}{|c|}{0.88} \\
\hline DF & \multicolumn{2}{|c|}{150.203} & \multicolumn{2}{|c|}{193.830} & \multicolumn{2}{|c|}{139.070} & \multicolumn{2}{|c|}{62.001} & \multicolumn{2}{|c|}{529.695} \\
\hline Welch t & \multicolumn{2}{|c|}{-3.600} & \multicolumn{2}{|c|}{-3.317} & \multicolumn{2}{|c|}{-5.120} & \multicolumn{2}{|c|}{-3.786} & \multicolumn{2}{|c|}{-7.766} \\
\hline $\mathrm{p}$ & \multicolumn{2}{|c|}{0.000} & \multicolumn{2}{|c|}{0.001} & \multicolumn{2}{|c|}{0.000} & \multicolumn{2}{|c|}{0.000} & \multicolumn{2}{|c|}{0.000} \\
\hline Spearman's $\rho$ & \multicolumn{2}{|c|}{0.124} & \multicolumn{2}{|c|}{0.117} & \multicolumn{2}{|c|}{0.183} & \multicolumn{2}{|c|}{0.138} & \multicolumn{2}{|c|}{0.135} \\
\hline
\end{tabular}

Source:Aauthor's own research based on Eurofound data. 
Table 18: Life satisfaction and financial problems - comparing means

\begin{tabular}{|c|c|c|c|c|c|c|c|c|c|c|}
\hline & \multicolumn{2}{|c|}{ Czech Republic } & \multicolumn{2}{|c|}{ Hungary } & \multicolumn{2}{|c|}{ Poland } & \multicolumn{2}{|c|}{ Slovakia } & \multicolumn{2}{|c|}{ ALL } \\
\hline & Unable & Able & Unable & Able & Unable & Able & Unable & Able & Unable & Able \\
\hline Mean & 5.83 & 6.62 & 5.63 & 6.48 & 5.94 & 7.40 & 5.05 & 6.28 & 5.69 & 6.67 \\
\hline Variance & 3.46 & 3.97 & 4.96 & 4.22 & 4.90 & 4.02 & 7.87 & 4.53 & 4.97 & 4.36 \\
\hline Std. dev. & 1.86 & 1.99 & 2.23 & 2.06 & 2.21 & 2.00 & 2.81 & 2.13 & 2.23 & 2.09 \\
\hline $\mathrm{N}$ & 115 & 819 & 142 & 688 & 113 & 674 & 58 & 810 & 428 & 2991 \\
\hline Mean diff. & \multicolumn{2}{|c|}{0.79} & \multicolumn{2}{|c|}{0.85} & \multicolumn{2}{|c|}{1.46} & \multicolumn{2}{|c|}{1.23} & \multicolumn{2}{|c|}{0.98} \\
\hline $\mathrm{DF}$ & \multicolumn{2}{|c|}{153.161} & \multicolumn{2}{|c|}{193.721} & \multicolumn{2}{|c|}{144.471} & \multicolumn{2}{|c|}{61.785} & \multicolumn{2}{|c|}{539.564} \\
\hline Welch t & \multicolumn{2}{|c|}{-4.222} & \multicolumn{2}{|c|}{-4.153} & \multicolumn{2}{|c|}{-6.593} & \multicolumn{2}{|c|}{-3.277} & \multicolumn{2}{|c|}{-8.602} \\
\hline $\mathrm{p}$ & \multicolumn{2}{|c|}{0.000} & \multicolumn{2}{|c|}{0.000} & \multicolumn{2}{|c|}{0.000} & \multicolumn{2}{|c|}{0.002} & \multicolumn{2}{|c|}{0.000} \\
\hline Spearman's $\rho$ & \multicolumn{2}{|c|}{0.137} & \multicolumn{2}{|c|}{0.151} & \multicolumn{2}{|c|}{0.232} & \multicolumn{2}{|c|}{0.123} & \multicolumn{2}{|c|}{0.149} \\
\hline
\end{tabular}

Source: Author's own research based on Eurofound data.

Table 19: Happiness and housing defects - comparing means

\begin{tabular}{|c|c|c|c|c|c|c|c|c|c|c|}
\hline & \multicolumn{2}{|c|}{ Czech Republic } & \multicolumn{2}{|c|}{ Hungary } & \multicolumn{2}{|c|}{ Poland } & \multicolumn{2}{|c|}{ Slovakia } & \multicolumn{2}{|c|}{ ALL } \\
\hline & Exist & $\begin{array}{l}\text { Don't } \\
\text { exist }\end{array}$ & Exist & $\begin{array}{c}\text { Don't } \\
\text { exist }\end{array}$ & Exist & $\begin{array}{l}\text { Don't } \\
\text { exist }\end{array}$ & Exist & $\begin{array}{c}\text { Don't } \\
\text { exist }\end{array}$ & Exist & $\begin{array}{l}\text { Don't } \\
\text { exist }\end{array}$ \\
\hline Mean & 6.41 & 6.82 & 6.09 & 7.00 & 6.77 & 7.53 & 6.05 & 6.92 & 6.37 & 7.05 \\
\hline Variance & 3.95 & 3.23 & 5.48 & 4.01 & 5.42 & 4.19 & 6.25 & 3.83 & 5.32 & 3.86 \\
\hline Std. dev. & 1.99 & 1.80 & 2.34 & 2.00 & 2.33 & 2.05 & 2.50 & 1.96 & 2.31 & 1.97 \\
\hline $\mathrm{N}$ & 158 & 852 & 272 & 767 & 253 & 740 & 101 & 915 & 784 & 3274 \\
\hline Mean diff. & \multicolumn{2}{|c|}{0.41} & \multicolumn{2}{|c|}{0.91} & \multicolumn{2}{|c|}{0.76} & \multicolumn{2}{|c|}{0.87} & \multicolumn{2}{|c|}{0.68} \\
\hline $\mathrm{DF}$ & \multicolumn{2}{|c|}{207.289} & \multicolumn{2}{|c|}{419.750} & \multicolumn{2}{|c|}{393.459} & \multicolumn{2}{|c|}{113.949} & \multicolumn{2}{|c|}{1071.196} \\
\hline Welch t & \multicolumn{2}{|c|}{-2.424} & \multicolumn{2}{|c|}{-5.718} & \multicolumn{2}{|c|}{-4.630} & \multicolumn{2}{|c|}{-3.384} & \multicolumn{2}{|c|}{-7.644} \\
\hline $\mathrm{p}$ & \multicolumn{2}{|c|}{0.016} & \multicolumn{2}{|c|}{0.000} & \multicolumn{2}{|c|}{0.000} & \multicolumn{2}{|c|}{0.001} & \multicolumn{2}{|c|}{0.000} \\
\hline Spearman's $\rho$ & \multicolumn{2}{|c|}{0.075} & \multicolumn{2}{|c|}{0.181} & \multicolumn{2}{|c|}{0.145} & \multicolumn{2}{|c|}{0.103} & \multicolumn{2}{|c|}{0.117} \\
\hline
\end{tabular}

Source: Author's own research based on Eurofound data.

Table 20: Life satisfaction and housing defects - comparing means

\begin{tabular}{|c|c|c|c|c|c|c|c|c|c|c|}
\hline & \multicolumn{2}{|c|}{ Czech Republic } & \multicolumn{2}{|c|}{ Hungary } & \multicolumn{2}{|c|}{ Poland } & \multicolumn{2}{|c|}{ Slovakia } & \multicolumn{2}{|c|}{ ALL } \\
\hline & Exist & $\begin{array}{l}\text { Don't } \\
\text { exist }\end{array}$ & Exist & $\begin{array}{c}\text { Don't } \\
\text { exist }\end{array}$ & Exist & $\begin{array}{c}\text { Don't } \\
\text { exist }\end{array}$ & Exist & $\begin{array}{c}\text { Don't } \\
\text { exist }\end{array}$ & Exist & $\begin{array}{c}\text { Don't } \\
\text { exist }\end{array}$ \\
\hline Mean & 5.97 & 6.59 & 5.56 & 6.67 & 6.40 & 7.28 & 5.43 & 6.32 & 5.90 & 6.69 \\
\hline Variance & 5.13 & 3.67 & 5.63 & 4.01 & 5.28 & 4.22 & 6.53 & 4.52 & 5.66 & 4.23 \\
\hline Std. dev. & 2.27 & 1.92 & 2.37 & 2.00 & 2.30 & 2.05 & 2.55 & 2.13 & 2.38 & 2.06 \\
\hline $\mathrm{N}$ & 158 & 852 & 272 & 767 & 253 & 740 & 101 & 915 & 784 & 3274 \\
\hline Mean diff. & \multicolumn{2}{|c|}{0.62} & \multicolumn{2}{|c|}{1.11} & \multicolumn{2}{|c|}{0.88} & \multicolumn{2}{|c|}{0.89} & \multicolumn{2}{|c|}{0.79} \\
\hline DF & \multicolumn{2}{|c|}{200.735} & \multicolumn{2}{|c|}{415.797} & \multicolumn{2}{|c|}{398.385} & \multicolumn{2}{|c|}{115.789} & \multicolumn{2}{|c|}{1079.807} \\
\hline Welch t & \multicolumn{2}{|c|}{-3.185} & \multicolumn{2}{|c|}{-6.873} & \multicolumn{2}{|c|}{-5.410} & \multicolumn{2}{|c|}{-3.387} & \multicolumn{2}{|c|}{-8.567} \\
\hline $\mathrm{p}$ & \multicolumn{2}{|c|}{0.002} & \multicolumn{2}{|c|}{0.000} & \multicolumn{2}{|c|}{0.000} & \multicolumn{2}{|c|}{0.001} & \multicolumn{2}{|c|}{0.000} \\
\hline Spearman's $\rho$ & \multicolumn{2}{|c|}{0.100} & \multicolumn{2}{|c|}{0.216} & \multicolumn{2}{|c|}{0.172} & \multicolumn{2}{|c|}{0.110} & \multicolumn{2}{|c|}{0.135} \\
\hline
\end{tabular}

Source: Author's own research based on Eurofound data. 
Based on the performed Welch t-tests, the null hypotheses of equality in the mean happiness, as well as the mean satisfaction between the two compared groups, are rejected in all examined cases, and the alternative hypotheses of different levels of both happiness and satisfaction need to be accepted.

The first test confirmed that there was a difference in happiness between those people who would be able to afford all six named items if they wanted to get them and those who would not. The resulting satisfaction was the same. People who can afford all items if they would like to get them are on average happier and more satisfied than people who cannot afford all of them (more precisely they cannot afford 1 to 6 out of the 6 named items). Hypotheses 5a and $5 b$ are thus both confirmed for all examined countries as well as for central Europe as a whole.

The second test compares the group of people who were able to make payments of all four inquired types of household bills as scheduled in the past 12 months and the group of those people who were unable to make timely payments of one to four inquired types in the past 12 months. The null hypotheses of equality in the mean happiness, as well as the mean satisfaction between the two groups, are rejected, and the alternative hypotheses of difference are accepted. People who were able to pay all their household bills timely are on average happier and more satisfied with their lives than those who were not able to make all payments as scheduled in the past 12 months (more precisely they could not afford 1 to 5 out of the 5 inquired payments). Both Hypotheses $6 \mathrm{a}$ and $6 \mathrm{~b}$ are thus confirmed for all examined countries as well as for central Europe as a whole.

The last examined factor is the number of problems with housing. The first group includes only respondents reporting no problems with housing, whereas respondents in the second group report 1 to 6 problems with housing. In terms of both happiness and satisfaction, the groups of people without housing problems are not identical with the groups of people facing problems with housing; hence the null hypotheses of equality in the means need to be rejected, and the alternative hypotheses are accepted. People who have had no problems with housing are happier and more satisfied with their lives than those who have. Both Hypotheses $7 \mathrm{a}$ and $7 \mathrm{~b}$ are thus confirmed for all examined countries as well as for central Europe as a whole.

Although statistical tests proved that SWB is negatively affected by ability to afford selected items, housing and financial problems, the differences seem to be rather minor comparing to ones found when having investigated the association with relative income and subjective economic strain. From the perspective of SWB, it seems that not having enough money to make ends meet is a more serious issue than not having enough money to afford what is wanted, 
to live in defective housing conditions, and to be in arrears with some payments.

Same variables based on EQLS data from $25 \mathrm{EU}$ countries and 3 candidate states were used by Fahey (2007) in a paper promoting a shift towards an EUwide poverty indicator. The author clustered the countries into 4 clusters and noticed that people in the lower-income quartile in the richest EU states are still less likely to be deprived and have fewer financial problems and housing defects on average than those in the upper-income quartile in the poorest EU countries. The situation in Europe as a whole in terms of poverty was also studied in the paper by Whelan and Maître (2007) using EQLS data for income, ability to afford selected items, and economic strain. They suggested income as a more powerful predictor of deprivation in the poorer countries than in richer ones. Still, SWB remained outside of the scope of this study. On the contrary, Zagorski et al. (2014) using also EQLS data, suggested that national-level income inequality as measured by Gini coefficient does not reduce individuals' overall SWB, subjective health, and financial quality of life (satisfaction with standard of living, subjective poverty, and affordability of goods and services) in advanced societies, all other equals (particularly GDP ${ }^{14}$ ).

\section{Conclusions}

All the outlined hypotheses were confirmed for central Europe as a whole. All of them were also confirmed in the cases of the Czech Republic and Poland. In the case of Slovakia there is no statistically significant difference of life satisfaction between the second (considered low-income) and third (considered high-income) quartiles; hence the hypothesis that people in low-income groups are on average more satisfied than people in high-income groups cannot be accepted for Slovakia. Contrary to that Želinský et al. (2018) found that the relationship between income and SWB score is positive and statistically significant in the Slovak population, whereas the marginal increase of income is diminished with higher income. In their study, the authors used different data $^{15}$ and a different concept of SWB ${ }^{16}$.

\footnotetext{
14 National per capita GDP increases subjective well-being, financial quality of life, and health.

15 European Union Statistics on Income and Living Conditions (EU-SILC) 2013 microdata (SO SR, 2014a) collected in the first half of 2013 .

${ }^{16}$ SWB is proxied by a subjective measure of psychological well-being, a component of mental health based on Mental Health Inventory (MHI-5) used for depressive symptoms. The set of the following questions focused on SWB and included in the EU-SILC 2013 ad-hoc module "Well-Being" were asked:

"During the last four weeks were you...

(A) Feeling very nervous?

(B) Feeling down in the dumps?

(C) Feeling calm and peaceful?

(D) Feeling downhearted or depressed?

(E) Happy?"
} 
Also, the statistically significant differences in both happiness and satisfaction were not proved between groups of those evaluating their financial situation much better comparing to others and those evaluating it either much worse or somewhat worse. It means that the hypotheses that those evaluating their financial situations as better compared to most people in the country are on average happier and/or more satisfied than those evaluating it as worse cannot be accepted either. Other outlined hypotheses can be accepted in the case of Slovakia.

Similarly, in Hungary the hypotheses that people in low-income groups are on average happier and more satisfied than people in high-income groups cannot be accepted because the differences of means for criterial pairs were found statistically insignificant. Hypotheses that people making ends meet easily are on average happier and more satisfied cannot be accepted in Hungary either, as the statistically significant differences were not proved between the relevant pairs. Other outlined hypotheses can be accepted in the case of Hungary.

Subjective economic strain together with relative income measured by subjective comparison of one's own financial situation with others seem to be more important than the income in absolute terms and relative to past financial situation. The differences of means between the best and worst group of the first two factor variables are apparently more substantial than the latter two. This observation applies to both happiness and satisfaction. Inequalities especially among income quartiles do not seem to be very alarming, although they are still statistically significant in most cases. Although the results of statistical tests are not identical, both happiness and satisfaction as the two components of SWB mostly show the similar patterns. It is also noticeable that, on average for all groups, people tend to score their happiness higher than their satisfaction on a 10-point scale considering all things together. On the other hand, the variance in happiness is on average lower than that in satisfaction for all groups.

Warning must be given against interpreting the results of this study causally. Instead of a causal link, the pure association between SWB and selected factors is examined. Neither higher income nor better material standards are roots of a high SWB level. The only result this study brings is that they exist side by side.

Jan Švorc is a Junior Research Fellow at the Institute of Information Theory and Automation (UTIA), the Czech Academy of Sciences, and a post graduate student at the Faculty of Management, University of Economics, Prague. His research is mainly focused on the application of the probability modelling techniques within the subjective well-being research. 


\section{REFERENCES}

ANDRESS, H. J. - LIPSMEIER, G., 2001: Armut und Lebensstandard. In: Gutachten im Rahmen des Armuts- und Reichtumsberichts der Bundesregierung. Bundesministerium für Arbeit und Sozialordnung, Information, Publikation, Redaktion.

ANDREWS, F. M. - WITHEY, S. B., 1976: Social Indicators of Well-Being. New York: Plenum Press. DOI: http://dx.doi.org/10.1007/978-1-4684-2253-5

CAPORALE, G. M. - GEORGELLIS, Y. - TSITSIANIS, N. - YIN, Y. P., 2009: Income and Happiness Across Europe: Do Reference Values Matter? Journal of Economic Psychology 30, No. 1, pp. 42-51.

DOI: http://dx.doi.org/10.1016/j.joep.2008.06.004

CARSTAIRS, V. - MORRIS, R., 1989: Deprivation: Explaining Differences in Mortality between Scotland and England and Wales. British Medical Journal 299, No. 6704, pp. 886-889. DOI: http://dx.doi.org/10.1136/bmj.299.6704.886

CHRISTOPH, B., 2010: The Relation between Life Satisfaction and the Material Situation: A Re-Evaluation Using Alternative Measures. Social Indicators Research 98, No. 3, pp. 475-499. DOI: http://dx.doi.org/10.1007/s11205-009-9552-4

CLARK, A. E. - FRIJTERS, P. - SHIELDS, M. A., 2008: Relative Income, Happiness, and Utility: An Explanation for the Easterlin Paradox and Other Puzzles. Journal of Economic Literature 46, No. 1, pp. 95-144. DOI: http://dx.doi.org/10.1257/jel.46.1.95

DIENER, E., 1984: Subjective Well-Being. Psychological Bulletin 95, No. 3, pp. $542-$ 575. DOI: http://dx.doi.org/10.1037/0033-2909.95.3.542

DIENER, E. - BISWAS-DIENER, R., 2002: Will Money Increase Subjective WellBeing? Social indicators research 57, No. 2, pp. 119-169. DOI: https://doi.org/10.1023/A:1014411319119

DIENER, E. - HORWITZ, J. - EMMONS, R. A., 1985: Happiness of the Very Wealthy. Social Indicators Research 16, No. 3, pp. 263-274. DOI: http://dx.doi.org/10.1007/BF00415126

DIENER, E. - LUCAS, R. E. - OISHI, S., 2002: Subjective Well-Being: The Science of Happiness and Life Satisfaction. In: Snyder, C. R. - Lopez, S. J. (eds.): Handbook of Positive Psychology. New York: Oxford University Press, pp. 63-73.

DIENER, E. - RYAN, K., 2009: Subjective Well-Being: A General Overview. South African Journal of Psychology 39, No. 4, pp. 391-406. DOI: http://dx.doi.org/10.1177/008124630903900402

DIENER, E. - SANDVIK, E. - SEIDLITZ, L. - DIENER, M., 1993: The Relationship between Income and Subjective Well-Being: Relative or Absolute? Social Indicators Research 28, No. 3, pp. 195-223. DOI: http://dx.doi.org/10.1007/BF01079018

DIENER, E. - SUH, E. M. - LUCAS, R. E. - SMITH, H. L., 1999: Subjective WellBeing: Three Decades of Progress. Psychological Bulletin 125, pp. 276-302. DOI: http://dx.doi.org/10.1037/0033-2909.125.2.276 
DITTMANN, J. - GOEBEL, J., 2010: Your House, your Car, your Education: The Socioeconomic Situation of the Neighborhood and its Impact on Life Satisfaction in Germany. Social Indicators Research 96, No. 3, pp. 497-513.

DOI: http://dx.doi.org/10.1007/s11205-009-9489-7

DOLAN, P. - PEASGOOD, T. - WHITE, M., 2008: Do We Really Know what Makes Us Happy? A Review of the Economic Literature on the Factors Associated with Subjective Well-Being. Journal of Economic Psychology 29, No. 1, pp. 94-122. DOI: http://dx.doi.org/10.1016/j.joep.2007.09.001

EUROFOUND (2018a): European Quality of Life Survey Integrated Data File [computer file], 2003 - 2016: 3rd Edition. UK Data Service. SN: 7348, http://doi.org/10.5255/UKDA-SN-7348-3.

EUROFOUND (2018b): Fourth European Quality of Life Survey: technical and fieldwork report.

FAHEY, T., 2007: The Case for an EU-Wide Measure of Poverty. European Sociological Review 23, No. 1, pp. 35-47. DOI: http://dx.doi.org/10.1093/esr/jcl018

FERRER-I-CARBONELL, A., 2005: Income and Well-Being: an Empirical Analysis of the Comparison Income Effect. Journal of Public Economics 89, No. 5, pp. 997 1019. DOI: http://dx.doi.org/10.1016/j.jpubeco.2004.06.003

FIALOVÁ, K. - ŚTIKA, P., 2015: Well-Being in the Czech Republic in an Aggregate Perspective. Review of Economic Perspectives 15, No. 1, pp. 71-88. DOI: http://dx.doi.org/10.1515/revecp-2015-0012

HAMPLOVÁ, D., 2004: Životní spokojenost: rodina, práce a další faktory. Sociologický ústav Akademie věd České republiky.

HAMPLOVÁ, D., 2006: Životní spokojenost, štěstí a rodinný stav v 21 evropských zemích. Sociologický časopis/Czech Sociological Review 42, No. 1, pp. 35-55.

HEADEY, B. - WOODEN, M., 2004: The Effects of Wealth and Income on Subjective Well-Being and Ill-Being. Economic Record 80, No. 1, pp. 24-33.

DOI: http://dx.doi.org/10.1111/j.1475-4932.2004.00181.x

HEŘMANOVÁ, E., 2012: Kvalita života a její modely v současném sociálním výzkumu. Sociológia 44, No. 4, pp. 407-425.

KAHNEMAN, D. - KRUEGER, A. B. - SCHKADE, D. - SCHWARTZ, N. STONE, A. A., 2006: Would you be Happier if you Were Richer? A Focusing Illusion. Science 312, No. 5782, pp. 1908-1910.

DOI: http://dx.doi.org/10.1126/science.1129688

KEBZA, V. - ŠOLCOVÁ, I., 2003: Well-Being jako psychologický a zároveň mezioborově založený pojem. Československá psychologie 47, No. 4, pp. 333-345.

LUTTMER, E. F., 2005: Neighbors as Negatives: Relative Earnings and Well-being. The Quarterly Journal of Economics 120, No. 3, pp. 963-1002.

DOI: http://dx.doi.org/10.1093/qje/120.3.963

MENTZAKIS, E. - MORO, M., 2009: The Poor, the Rich and the Happy: Exploring the Link between Income and Subjective Well-Being. The Journal of SocioEconomics 38, No. 1, pp. 147-158.

DOI: http://dx.doi.org/10.1016/j.socec.2008.07.010

MLČOCH, L., 2007: Ekonomie a štěstí: proč více někdy není lépe. Politická ekonomie 55, No. 2, pp. 147-163. DOI: http://dx.doi.org/10.18267/j.polek.594 
MYSÍKOVÁ, M. - VEČERNÍK, J., 2016: Spokojenost se životem a zaměstnáním v České republice. Politická ekonomie 64, No. 7, pp. 851-866.

DOI: https://doi.org/10.18267/j.polek.1093

RINGEN, S., 1988: Direct and Indirect Measures of Poverty. Journal of social policy 17, No. 3, pp. 351-365. DOI: http://dx.doi.org/10.1017/S0047279400016858

SAUNDERS, M. - LEWIS, P. - THORNHILL, A., 2009: Research Methods for Business Students. 5th edition, Pearson Education.

TOWNSEND, P., 1979: Poverty in the United Kingdom: A Survey of Household Resources and Standards of Living. Harmondsworth: Penguin Books (Reprinted 1983). ISBN 0-14-022139-5.

TOWNSEND, P. - PHILLIMORE, P. - BEATTIE, A., 1986: Inequalities in Health in the Northern Region. Newcastle upon Tyne: Northern Regional Health Authority and University of Bristol.

URDAN, T. C., 2016: Statistics in Plain English. Taylor \& Francis.

DOI: http://dx.doi.org/10.4324/9781410612816

VEČERNÍK, J., 2014: Subjektivní blahobyt v České republice a střední Evropě: makro-a mikro-determinanty. Politická ekonomie 62, No. 2, pp. 249-269. DOI: https://doi.org/10.18267/j.polek.949

VEČERNÍK, J. - MYSÍKOVÁ, M., 2014: (Un)Happy Transition? Subjective WellBeing in European Countries in $1991-2008$ and Beyond. WIFO Working Papers.

VEENHOVEN, R., 1984: Conditions of Happiness, Boston: Riedel. DOI: http://dx.doi.org/10.1007/978-94-009-6432-7

VEENHOVEN, R., 2008: Sociological Theories of Subjective Well-Being. In: Eid, M. - Larsen, R. (eds.): The Science of Subjective Well-Being. New York: Guilford Publications, pp. 44-61.

WHELAN, C. T. - MAÎTRE, B., 2007: Income, Deprivation and Economic Stress in the Enlarged European Union. Social Indicators Research 83, No 2, pp. 309-329. DOI: http://dx.doi.org/10.1007/s11205-006-9051-9

ZAGORSKI, K. - EVANS, M. D. - KELLEY, J. - PIOTROWSKA, K., 2014: Does National Income Inequality Affect Individuals' Quality of Life in Europe? Inequality, Happiness, Finances, and Health. Social Indicators Research 117, No. 3 , pp. 1089-1110. DOI: http://dx.doi.org/10.1007/s11205-013-0390-z

ŽELINSKÝ, T. - SOROKOVÁ, T. - PETRÍKOVÁ, D., 2018: Economic Characteristics and Subjective Well-Being. Sociológia 50, No. 3, pp. 334-364. 
Appendix 1: Bartlett's tests for homogeneity of variances

\begin{tabular}{|c|c|c|c|c|c|c|c|}
\hline \multirow{2}{*}{ Factor } & \multirow{2}{*}{ Country } & \multicolumn{3}{|c|}{ Happiness } & \multicolumn{3}{|c|}{ Life satisfaction } \\
\hline & & Chi sq. & DF & $\mathbf{p}$ & Chi sq. & DF & $\mathbf{p}$ \\
\hline \multirow{5}{*}{$\begin{array}{l}\text { Level of income } \\
\text { (INCOME) }\end{array}$} & Czech Republic & 4,79 & 3 & 0,187 & 10,75 & 3 & 0,013 \\
\hline & Hungary & 5,35 & 3 & 0,148 & 17,54 & 3 & 0,001 \\
\hline & Poland & 7,12 & 3 & 0,068 & 4,11 & 3 & 0,250 \\
\hline & Slovakia & 22,80 & 3 & 0,000 & 6,91 & 3 & 0,075 \\
\hline & All & 21,98 & 3 & 0,000 & 25,84 & 3 & 0,000 \\
\hline \multirow{5}{*}{$\begin{array}{l}\text { Fin. situation } \\
\text { comparing to others } \\
\text { (FINSITEVAL) }\end{array}$} & Czech Republic & 10,69 & 4 & 0,030 & 16,01 & 4 & 0,003 \\
\hline & Hungary & 30,74 & 4 & 0,000 & 9,21 & 4 & 0,056 \\
\hline & Poland & 69,39 & 4 & 0,000 & 90,27 & 4 & 0,000 \\
\hline & Slovakia & 23,59 & 4 & 0,000 & 15,36 & 4 & 0,004 \\
\hline & All & 116,52 & 4 & 0,000 & 75,46 & 4 & 0,000 \\
\hline \multirow{5}{*}{$\begin{array}{l}\text { Fin. situation } \\
\text { comparing to past } \\
\text { (PASTFIN) }\end{array}$} & Czech Republic & 3,23 & 2 & 0,199 & 2,72 & 2 & 0,257 \\
\hline & Hungary & 10,32 & 2 & 0,006 & 14,92 & 2 & 0,001 \\
\hline & Poland & 6,47 & 2 & 0,039 & 1,09 & 2 & 0,580 \\
\hline & Slovakia & 12,59 & 2 & 0,002 & 15,94 & 2 & 0,000 \\
\hline & All & 16,10 & 2 & 0,000 & 12,74 & 2 & 0,002 \\
\hline \multirow{5}{*}{$\begin{array}{l}\text { Subjective economic } \\
\text { strain (MEETENDS) }\end{array}$} & Czech Republic & 9,00 & 5 & 0,109 & 8,56 & 5 & 0,128 \\
\hline & Hungary & 16,95 & 5 & 0,005 & 21,57 & 5 & 0,001 \\
\hline & Poland & 36,81 & 5 & 0,000 & 19,29 & 5 & 0,002 \\
\hline & Slovakia & 31,56 & 5 & 0,000 & 23,99 & 5 & 0,000 \\
\hline & All & 74,70 & 5 & 0,000 & 59,49 & 5 & 0,000 \\
\hline \multirow{5}{*}{$\begin{array}{l}\text { Ability to afford } \\
\text { selected items } \\
\text { (WANTED) }\end{array}$} & Czech Republic & $\mathbf{0 , 0 2}$ & 1 & 0,895 & 0,90 & 1 & 0,342 \\
\hline & Hungary & 8,87 & 1 & 0,003 & 30,50 & 1 & 0,000 \\
\hline & Poland & 18,16 & 1 & 0,000 & 14,44 & 1 & 0,000 \\
\hline & Slovakia & 7,41 & 1 & 0,006 & 8,16 & 1 & 0,004 \\
\hline & All & 30,92 & 1 & 0,000 & 39,47 & 1 & 0,000 \\
\hline \multirow{5}{*}{$\begin{array}{l}\text { Financial problems } \\
\text { (UNABLEPAY) }\end{array}$} & Czech Republic & $\mathbf{0 , 2 0}$ & 1 & 0,656 & 0,92 & 1 & 0,338 \\
\hline & Hungary & 1,51 & 1 & 0,219 & 1,55 & 1 & 0,213 \\
\hline & Poland & 7,24 & 1 & 0,007 & 1,97 & 1 & 0,161 \\
\hline & Slovakia & 7,98 & 1 & 0,005 & 9,52 & 1 & 0,002 \\
\hline & All & 9,55 & 1 & 0,002 & $\mathbf{3 , 3 8}$ & 1 & 0,066 \\
\hline \multirow{5}{*}{$\begin{array}{l}\text { Housing defects } \\
\text { (ACCOMP) }\end{array}$} & Czech Republic & 2,83 & 1 & 0,092 & 8,04 & 1 & 0,005 \\
\hline & Hungary & 10,28 & 1 & 0,001 & 12,11 & 1 & 0,001 \\
\hline & Poland & 6,47 & 1 & 0,011 & 4,88 & 1 & 0,027 \\
\hline & Slovakia & 12,21 & 1 & 0,000 & 6,72 & 1 & 0,010 \\
\hline & All & 34,49 & 1 & 0,000 & 28,55 & 1 & 0,000 \\
\hline
\end{tabular}


Appendix 2: Results of post hoc testing

Happiness and income - details for post hoc testing

\begin{tabular}{|c|c|c|c|c|c|c|c|c|c|c|c|c|c|c|c|c|c|c|c|c|c|}
\hline \multirow{2}{*}{ Group1 } & \multirow{2}{*}{ Group2 } & \multicolumn{4}{|c|}{ Czech Republic } & \multicolumn{4}{|c|}{ Hungary } & \multicolumn{4}{|c|}{ Poland } & \multicolumn{4}{|c|}{ Slovakia } & \multicolumn{4}{|c|}{ All } \\
\hline & & Welch t & D.F & Welch p & Diff & Welch $\mathbf{t}$ & D.F & Welch p & Diff & Welch $\mathbf{t}$ & D.F & Welch p & Diff & Welch $\mathbf{t}$ & D.F & Welch p & Diff & Welch $\mathbf{t}$ & D.F & Welch p & Diff \\
\hline 1 & 2 & $-0,506$ & 137,56 & 0,614 & No & $-3,397$ & 434,97 & 0,001 & YES & $-0,436$ & 350,29 & 0,663 & NO & $-3,004$ & 362,50 & 0,003 & YES & $-3,259$ & 1446,49 & 0,001 & YES \\
\hline 1 & 3 & $-3,097$ & 134,43 & 0,002 & YES & $-5,026$ & 357,33 & 0,000 & YES & $-4,408$ & 349,19 & 0,000 & YES & $-5,877$ & 325,71 & 0,000 & YES & $-8,593$ & 1423,11 & 0,000 & YES \\
\hline 1 & 4 & $-3,224$ & 126,25 & 0,002 & YES & $-4,239$ & 350,23 & 0,000 & YES & $-4,819$ & 404,39 & 0,000 & YES & $-5,282$ & 340,76 & 0,000 & YES & $-8,645$ & 1437,73 & 0,000 & YES \\
\hline 2 & 3 & $-3,587$ & 370,39 & 0,000 & YES & $-1,667$ & 335,58 & 0,096 & NO & $-3,683$ & 316,40 & 0,000 & YES & $-3,033$ & 398,39 & 0,003 & YES & $-5,534$ & 1458,32 & 0,000 & YES \\
\hline 2 & 4 & $-3,815$ & 352,28 & 0,000 & YES & $-1,041$ & 334,93 & 0,299 & No & $-3,981$ & 321,01 & 0,000 & YES & $-2,779$ & 332,46 & 0,006 & YES & $-5,655$ & 1456,76 & 0,000 & YES \\
\hline 3 & 4 & $-0,103$ & 438,75 & 0,918 & NO & 0,546 & 306,03 & 0,586 & No & $-0,023$ & 319,77 & 0,981 & No & $-0,300$ & 294,62 & 0,765 & NO & $-0,271$ & 1455,78 & 0,787 & No \\
\hline
\end{tabular}

Life satisfaction and income - details for post hoc testing

\begin{tabular}{|c|c|c|c|c|c|c|c|c|c|c|c|c|c|c|c|c|c|c|c|c|c|}
\hline \multirow{2}{*}{ Group1 } & \multirow{2}{*}{ Group2 } & \multicolumn{4}{|c|}{ Czech Republic } & \multicolumn{4}{|c|}{ Hungary } & \multicolumn{4}{|c|}{ Poland } & \multicolumn{4}{|c|}{ Slovakia } & \multicolumn{4}{|c|}{ All } \\
\hline & & Welch $t$ & D.F & Welch p & Diff & Welch $t$ & D.F & Welch p & Diff & Welch $t$ & D.F & Welch p & Diff & Welch $t$ & D.F & Welch p & Diff & Welch $t$ & D.F & Welch p & Diff \\
\hline 1 & 2 & $-1,935$ & 132,69 & 0,055 & NO & $-3,948$ & 447,44 & 0,000 & YES & $-0,693$ & 347,54 & 0,489 & NO & $-3,574$ & 365,84 & 0,000 & YES & $-4,537$ & 1434,27 & 0,000 & YES \\
\hline 1 & 3 & $-4,556$ & 126,67 & 0,000 & YES & $-5,834$ & 372,83 & 0,000 & YES & $-6,115$ & 353,20 & 0,000 & YES & $-5,177$ & 354,25 & 0,000 & YES & $-10,011$ & 1427,35 & 0,000 & YES \\
\hline 1 & 4 & $-5,061$ & 115,00 & 0,000 & YES & $-5,083$ & 383,35 & 0,000 & YES & $-5,853$ & 403,67 & 0,000 & YES & $-5,802$ & 340,43 & 0,000 & YES & $-10,844$ & 1425,00 & 0,000 & YES \\
\hline 2 & 3 & $-3,740$ & 365,81 & 0,000 & YES & $-2,174$ & 326,89 & 0,030 & YES & $-4,957$ & 314,74 & 0,000 & YES & $-1,689$ & 409,13 & 0,092 & NO & $-5,848$ & 1464,98 & 0,000 & YES \\
\hline 2 & 4 & $-4,532$ & 335,69 & 0,000 & YES & $-1,395$ & 336,57 & 0,164 & NO & $-4,682$ & 334,21 & 0,000 & YES & $-2,740$ & 334,77 & 0,006 & YES & $-6,760$ & 1456,82 & 0,000 & YES \\
\hline 3 & 4 & $-0,594$ & 434,60 & 0,553 & No & 0,738 & 306,87 & 0,461 & No & 0,404 & 336,11 & 0,687 & No & $-1,286$ & 322,52 & 0,199 & NO & $-0,949$ & 1460,67 & 0,343 & No \\
\hline
\end{tabular}


Happiness and relative income comparing to others - details for post hoc testing

\begin{tabular}{|c|c|c|c|c|c|c|c|c|c|c|c|c|c|c|c|c|c|c|c|c|c|}
\hline \multirow{2}{*}{ Group1 } & \multirow{2}{*}{ Group2 } & \multicolumn{4}{|c|}{$\begin{array}{c}\text { Czech Republic } \\
\end{array}$} & \multicolumn{4}{|c|}{ Hungary } & \multicolumn{4}{|c|}{ Poland } & \multicolumn{4}{|c|}{ Slovakia } & \multicolumn{4}{|c|}{ All } \\
\hline & & Welch $t$ & D.F & Welch p & Diff & Welch $t$ & D.F & Welch p & Diff & Welch $\mathbf{t}$ & D.F & Welch p & Diff & Welch t & D.F & Welch p & Diff & Welch $\mathbf{t}$ & D.F & Welch p & Diff \\
\hline 1 & 2 & $-2,759$ & 67,66 & 0,007 & YES & $-1,453$ & 96,89 & 0,150 & NO & $-4,484$ & 265,44 & 0,000 & YES & $-4,017$ & 189,18 & 0,000 & YES & $-6,464$ & 610,76 & 0,000 & YES \\
\hline 1 & 3 & $-6,722$ & 54,70 & 0,000 & YES & $-4,502$ & 76,39 & 0,000 & YES & $-9,804$ & 186,15 & 0,000 & YES & $-9,162$ & 142,18 & 0,000 & YES & $-15,284$ & 456,58 & 0,000 & YES \\
\hline 1 & 4 & $-7,114$ & 67,86 & 0,000 & YES & $-6,156$ & 96,06 & 0,000 & YES & $-11,432$ & 247,52 & 0,000 & YES & $-9,781$ & 202,15 & 0,000 & YES & $-17,650$ & 605,64 & 0,000 & YES \\
\hline 1 & 5 & $-6,151$ & 67,69 & 0,000 & YES & $-5,590$ & 32,74 & 0,000 & YES & $-12,761$ & 235,16 & 0,000 & YES & $-1,738$ & 10,23 & 0,112 & NO & $-15,562$ & 326,41 & 0,000 & YES \\
\hline 2 & 3 & $-7,723$ & 409,83 & 0,000 & YES & $-5,954$ & 353,50 & 0,000 & YES & $-8,289$ & 604,46 & 0,000 & YES & $-7,495$ & 423,26 & 0,000 & YES & $-14,825$ & 1783,50 & 0,000 & YES \\
\hline 2 & 4 & $-7,660$ & 389,07 & 0,000 & YES & $-8,127$ & 323,65 & 0,000 & YES & $-10,349$ & 710,73 & 0,000 & YES & $-8,042$ & 261,10 & 0,000 & YES & $-17,393$ & 1734,27 & 0,000 & YES \\
\hline 2 & 5 & $-5,175$ & 38,44 & 0,000 & YES & $-5,466$ & 18,30 & 0,000 & YES & $-11,599$ & 160,03 & 0,000 & YES & $-0,592$ & 9,40 & 0,568 & NO & $-13,078$ & 184,03 & 0,000 & YES \\
\hline 3 & 4 & $-1,623$ & 289,38 & 0,106 & YES & $-4,131$ & 213,16 & 0,000 & YES & $-4,689$ & 488,13 & 0,000 & YES & $-2,827$ & 177,78 & 0,005 & YES & $-6,816$ & 1174,89 & 0,000 & YES \\
\hline 3 & 5 & $-1,991$ & 32,21 & 0,055 & No & $-3,494$ & 15,95 & 0,003 & YES & $-7,365$ & 94,62 & 0,000 & YES & 0,713 & 9,16 & 0,493 & NO & $-6,887$ & 147,41 & 0,000 & YES \\
\hline 4 & 5 & $-1,209$ & 38,59 & 0,234 & NO & $-1,926$ & 18,29 & 0,070 & NO & $-3,730$ & 145,01 & 0,000 & YES & 1,273 & 9,61 & 0,233 & NO & $-3,472$ & 184,29 & 0,001 & YES \\
\hline
\end{tabular}

\section{Happiness and relative income comparing to past - details for post hoc testing}

\begin{tabular}{|c|c|c|c|c|c|c|c|c|c|c|c|c|c|c|c|c|c|c|c|c|c|}
\hline \multirow{2}{*}{ Group1 } & \multirow{2}{*}{ Group2 } & \multicolumn{4}{|c|}{ Czech Republic } & \multicolumn{4}{|c|}{ Hungary } & \multicolumn{4}{|c|}{ Poland } & \multicolumn{4}{|c|}{ Slovakia } & \multicolumn{4}{|c|}{ All } \\
\hline & & Welch $\mathbf{t}$ & D.F & Welch p & Diff & Welch $t$ & D.F & Welch p & Diff & Welch $t$ & D.F & Welch p & Diff & Welch $t$ & D.F & Welch p & Diff & Welch $\mathrm{t}$ & D.F & Welch p & Diff \\
\hline 1 & 2 & 1,066 & 167,78 & 0,288 & NO & 2,984 & 123,40 & 0,003 & YES & 2,269 & 177,31 & 0,024 & YES & 4,277 & 118,72 & 0,000 & YES & 5,110 & 581,81 & 0,000 & YES \\
\hline 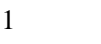 & 3 & 3,161 & 262,80 & 0,002 & YES & 5,968 & 224,69 & 0,000 & YES & 6,960 & 282,49 & 0,000 & YES & 6,960 & 231,30 & 0,000 & YES & 11,345 & 1016,78 & 0,000 & YES \\
\hline & 3 & 3,259 & 222,81 & 0,001 & YES & 5,123 & 247,41 & 0,000 & YES & 6,570 & 250,03 & 0,000 & YES & 4,901 & 213,34 & 0,000 & YES & 9,937 & 932,96 & 0,000 & YES \\
\hline
\end{tabular}


Life satisfation and relative income comparing to others - details for post hoc testing

\begin{tabular}{|c|c|c|c|c|c|c|c|c|c|c|c|c|c|c|c|c|c|c|c|c|c|}
\hline \multirow{2}{*}{ Group1 } & \multirow{2}{*}{ Group2 } & \multicolumn{4}{|c|}{ Czech Republic } & \multicolumn{4}{|c|}{ Hungary } & \multicolumn{4}{|c|}{ Poland } & \multicolumn{4}{|c|}{ Slovakia } & \multicolumn{4}{|c|}{ All } \\
\hline & & Welch $t$ & D.F & Welch p & Diff & Welch $\mathbf{t}$ & $\begin{array}{l}\text { D.F } \\
\end{array}$ & Welch $\mathrm{p}$ & p Diff & Welch $\mathbf{t}$ & D.F & Welch p & Diff & Welch $\mathbf{t}$ & D.F & Welch p & Diff & Welch $\mathbf{t}$ & D.F & Welch p & Diff \\
\hline & 2 & $-1,831$ & 68,24 & & NO & $-2,201$ & 105,43 & 0,030 & YES & $-4,986$ & 262,42 & 0,000 & YES & $-6,125$ & 216,12 & 0,000 & YES & $-7,432$ & 649,24 & 0,000 & $\overline{\text { YES }}$ \\
\hline & 3 & 5,844 & 54,62 & 0,000 & YES & $-6,609$ & 81,01 & 0,000 & YES & $-11,175$ & 185,35 & 0,000 & YES & $-11,627$ & 152,11 & 0,000 & YES & $-17,950$ & 469,25 & 0,000 & YES \\
\hline & 4 & $-7,013$ & 67,64 & 0,000 & YES & $-8,442$ & 113,13 & 0,000 & YES & $-12,137$ & 247,18 & 0,000 & YES & $-13,177$ & 210,74 & 0,000 & YES & $-20,516$ & 642,73 & 0,000 & YES \\
\hline & 5 & $-4,372$ & 57,69 & 0,000 & YES & $-7,675$ & 35,50 & 0,000 & YES & $-15,604$ & 238,98 & 0,000 & YES & $-1,753$ & 10,03 & 0,110 & NO & $-16,884$ & 288,78 & 0,000 & YES \\
\hline & 3 & $-7,850$ & 403,28 & 0,000 & YES & $-7,502$ & 380,03 & 0,000 & YES & $-9,842$ & 603,50 & 0,000 & YES & $-6,553$ & 416,09 & 0,000 & YES & $-16,299$ & 1797,15 & 0,000 & YES \\
\hline & 4 & $-9,054$ & 391,70 & 0,000 & YES & $-9,493$ & 301,89 & 0,000 & YES & $-10,752$ & 709,59 & 0,000 & YES & $-9,017$ & 278,70 & 0,000 & YES & $-19,118$ & 1731,79 & 0,000 & YES \\
\hline & 5 & $-3,758$ & 35,23 & 0,001 & YES & $-7,254$ & 19,95 & 0,000 & YES & $-15,379$ & 205,36 & 0,000 & YES & $-0,053$ & 9,46 & 0,959 & NO & $-13,630$ & 180,35 & 0,000 & YES \\
\hline & 4 & $-3,185$ & 289,19 & 0,002 & YES & $-4,353$ & 208,34 & 0,000 & YES & $-3,611$ & 482,45 & 0,000 & YES & $-4,632$ & 185,60 & 0,000 & YES & $-7,454$ & 1181,10 & 0,000 & YES \\
\hline & 5 & $-1,015$ & 31,06 & 0,318 & NO & $-4,247$ & 16,70 & 0,001 & YES & $-10,120$ & 103,97 & 0,000 & YES & 1,165 & 9,17 & 0,273 & NO & $-6,961$ & 146,67 & 0,000 & YES \\
\hline & 5 & 0,136 & 35,10 & 0,893 & NO & $-2,001$ & 21,31 & 0,058 & NO & $-6,078$ & 183,63 & 0,000 & YES & 2,089 & 9,60 & 0,064 & NO & $-3,366$ & 180,95 & 0,001 & YES \\
\hline
\end{tabular}

Life satisfaction and relative income comparing to past - details for post hoc testing

\begin{tabular}{|c|c|c|c|c|c|c|c|c|c|c|c|c|c|c|c|c|c|c|c|c|c|}
\hline \multirow{2}{*}{ Group1 } & \multirow{2}{*}{ Group2 } & \multicolumn{4}{|c|}{ Czech Republic } & \multicolumn{4}{|c|}{ Hungary } & \multicolumn{4}{|c|}{ Poland } & \multicolumn{4}{|c|}{ Slovakia } & \multicolumn{4}{|c|}{ All } \\
\hline & & Welch $t$ & D.F & Welch p & Diff & Welch t & D.F & Welch p & Diff & Welch $\mathbf{t}$ & D.F & Welch p & Diff & Welch $\mathbf{t}$ & D.F & Welch p & Diff & Welch t & D.F & Welch p & Diff \\
\hline & 2 & 0,551 & 168,68 & 0,582 & NO & 2,931 & 141,25 & 0,004 & YES & 0,999 & 168,30 & 0,319 & NO & 3,852 & 113,41 & 0,000 & YES & 4,158 & 590,81 & 0,000 & YES \\
\hline 1 & 3 & 3,694 & 262,24 & 0,000 & YES & 7,777 & 262,38 & 0,000 & YES & 6,867 & 262,52 & 0,000 & YES & 6,552 & 224,53 & 0,000 & YES & 12,268 & 1021,64 & 0,000 & YES \\
\hline & 3 & 4,623 & 225,07 & 0,000 & YES & 7,083 & 252,25 & 0,000 & YES & 8,170 & 265,82 & 0,000 & YES & 4,891 & 208,38 & 0,000 & YES & 12,124 & 944,41 & 0,000 & YES \\
\hline
\end{tabular}


Happiness and subjective economic strain - details for post hoc testing

\begin{tabular}{|c|c|c|c|c|c|c|c|c|c|c|c|c|c|c|c|c|c|c|c|c|c|}
\hline \multirow{2}{*}{ Group1 } & \multirow{2}{*}{ Group2 } & \multicolumn{4}{|c|}{ Czech Republic } & \multicolumn{4}{|c|}{ Hungary } & \multicolumn{4}{|c|}{ Poland } & \multicolumn{4}{|c|}{ Slovakia } & \multicolumn{4}{|c|}{ All } \\
\hline & & Welch $\mathbf{t}$ & D.F & Welch p & Diff & Welch $\mathbf{t}$ & D.F & Welch $p$ & Diff & Welch $\mathbf{t}$ & D.F & Welch p & Diff & Welch t & D.F & Welch $p$ & Diff & Welch $\mathbf{t}$ & D.F & Welch p & Diff \\
\hline 1 & 2 & $-0,892$ & 62,20 & 0,376 & NO & $-0,545$ & 16,60 & 0,593 & NO & 0,927 & 57,01 & 0,358 & NO & 3,056 & 49,05 & 0,004 & YES & 0,960 & 179,52 & 0,338 & NO \\
\hline 1 & 3 & 0,508 & 47,95 & 0,614 & NO & $-0,187$ & 14,85 & 0,855 & No & 3,162 & 48,82 & 0,003 & YES & 4,975 & 40,12 & 0,000 & YES & 3,744 & 148,96 & 0,000 & YES \\
\hline 1 & 4 & 2,038 & 49,84 & 0,047 & YES & 0,773 & 14,48 & 0,452 & No & 5,528 & 57,16 & 0,000 & YES & 6,583 & 35,07 & 0,000 & YES & 6,861 & 147,23 & 0,000 & YES \\
\hline 1 & 5 & 3,834 & 67,29 & 0,000 & YES & 1,763 & 16,20 & 0,097 & NO & 6,317 & 88,94 & 0,000 & YES & 8,315 & 47,66 & 0,000 & YES & 9,648 & 196,34 & 0,000 & YES \\
\hline 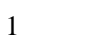 & 6 & 4,520 & 60,94 & 0,000 & YES & 3,697 & 22,09 & 0,001 & YES & 6,411 & 84,18 & 0,000 & YES & 8,744 & 87,13 & 0,000 & YES & 11,912 & 312,31 & 0,000 & YES \\
\hline & 3 & 2,788 & 238,37 & 0,006 & YES & 1,099 & 165,50 & 0,273 & No & 4,180 & 328,16 & 0,000 & YES & 2,797 & 231,57 & 0,006 & YES & 5,566 & 953,63 & 0,000 & YES \\
\hline 2 & 4 & 5,542 & 263,59 & 0,000 & YES & 4,132 & 136,71 & 0,000 & YES & 7,976 & 392,70 & 0,000 & YES & 5,508 & 182,47 & 0,000 & YES & 12,015 & 927,05 & 0,000 & YES \\
\hline 0 & 5 & 7,437 & 208,54 & 0,000 & YES & 5,896 & 211,49 & 0,000 & YES & 7,818 & 168,57 & 0,000 & YES & 7,859 & 262,02 & 0,000 & YES & 14,843 & 964,87 & 0,000 & YES \\
\hline , & 6 & 6,241 & 37,35 & 0,000 & YES & 7,921 & 93,65 & 0,000 & YES & 6,843 & 58,61 & 0,000 & YES & 7,749 & 88,50 & 0,000 & YES & 14,477 & 270,20 & 0,000 & YES \\
\hline & 4 & 4,022 & 648,99 & 0,000 & YES & 4,471 & 531,19 & 0,000 & YES & 4,945 & 505,11 & 0,000 & YES & 3,043 & 402,59 & 0,002 & YES & 8,477 & 2610,24 & 0,000 & YES \\
\hline & 5 & 6,393 & 137,40 & 0,000 & YES & 6,203 & 221,91 & 0,000 & YES & 5,564 & 139,00 & 0,000 & YES & 6,136 & 315,33 & 0,000 & YES & 12,188 & 787,52 & 0,000 & YES \\
\hline 3 & 6 & 5,325 & 30,75 & 0,000 & YES & 7,982 & 69,01 & 0,000 & YES & 5,362 & 53,54 & 0,000 & YES & 6,551 & 76,06 & 0,000 & YES & 12,474 & 225,71 & 0,000 & YES \\
\hline 4 & 5 & 3,612 & 151,84 & 0,000 & YES & 3,438 & 182,30 & 0,001 & YES & 2,154 & 172,89 & 0,033 & YES & 4,258 & 262,67 & 0,000 & YES & 6,564 & 765,25 & 0,000 & YES \\
\hline 4 & 6 & & 31,62 & 0,000 & YES & 6,341 & 63,37 & 0,000 & YES & 3,342 & 58,64 & 0,001 & YES & 5,473 & 68,66 & 0,000 & YES & 9,430 & 223,15 & 0,000 & YES \\
\hline 5 & 6 & 2,053 & 39,99 & 0,047 & YES & 3,982 & 89,07 & 0,000 & YES & 1,844 & 79,36 & 0,069 & No & 3,150 & 86,77 & 0,002 & YES & 5,487 & 294,09 & 0,000 & YES \\
\hline
\end{tabular}


Life satisfaction and subjective economic strain - details for post hoc testing

\begin{tabular}{|c|c|c|c|c|c|c|c|c|c|c|c|c|c|c|c|c|c|c|c|c|c|}
\hline \multirow{2}{*}{ Group1 } & \multirow{2}{*}{ Group2 } & \multicolumn{4}{|c|}{ Czech Republic } & \multicolumn{4}{|c|}{ Hungary } & \multicolumn{4}{|c|}{ Poland } & \multicolumn{4}{|c|}{ Slovakia } & \multicolumn{4}{|c|}{ All } \\
\hline & & Welch $\mathbf{t}$ & D.F & Welch p & Diff & Welch $\mathbf{t}$ & D.F & Welch p & Diff & Welch $\mathbf{t}$ & D.F & Welch p & Diff & Welch $\mathbf{t}$ & D.F & Welch p & Diff & Welch $\mathbf{t}$ & D.F & Welch p & Diff \\
\hline 1 & 2 & 0,535 & 70,85 & 0,594 & NO & 0,282 & 16,38 & 0,781 & NO & 2,166 & 62,28 & 0,034 & YES & 2,020 & 40,01 & 0,050 & NO & 2,521 & 184,82 & 0,013 & YES \\
\hline 1 & 3 & 2,271 & 49,49 & 0,028 & YES & 0,602 & 14,77 & 0,556 & No & 3,940 & 50,36 & 0,000 & YES & 2,906 & 36,53 & 0,006 & YES & 4,829 & 150,48 & 0,000 & YES \\
\hline & 4 & 4,431 & 52,21 & 0,000 & YES & 1,866 & 14,51 & 0,820 & NO & 7,496 & 59,45 & 0,000 & YES & 4,573 & 32,85 & 000 & YES & 9,303 & 148,44 & 0,000 & YES \\
\hline & 5 & 6,474 & 80,37 & 0,000 & YES & 3,506 & 16,81 & 0,003 & YES & 8,049 & 88,85 & 000 & YES & 6,042 & 41,41 & & YES & 12,582 & & 0,000 & YES \\
\hline & 6 & 6,313 & 56,91 & 0,000 & YES & 5,427 & 20,94 & 0,000 & YES & 7,450 & 85,31 & 0,000 & YES & 7,947 & 66,84 & 0,000 & YES & 14,739 & 307,78 & 0,000 & YES \\
\hline & 3 & 2,759 & 227,89 & 0,006 & YES & 0,956 & 164,70 & 0,340 & NO & 2,828 & 312,96 & 0,005 & YES & 1,716 & 250,57 & 0,087 & NO & 4,234 & 943,68 & 0,000 & YES \\
\hline & 4 & 6,176 & 254,05 & 0,000 & YES & 5,016 & 142,74 & 0,000 & YES & 8,445 & 378,00 & 0,000 & YES & 5,528 & 186,48 & 0,000 & YES & 13,078 & 913,70 & 0,000 & YES \\
\hline & 5 & 8,207 & 202,49 & 0,000 & YES & 7,990 & 219,67 & 0,000 & YES & 8,383 & 186,02 & 0,000 & YES & 7,553 & 270,68 & 0,000 & YES & 16,414 & 950,84 & 0,000 & YES \\
\hline & 6 & 6,857 & 38,91 & 0,000 & YES & 10,233 & 95,96 & 0,000 & YES & 7,007 & 62,96 & 0,000 & YES & 8,970 & 92,29 & 0,000 & YES & 16,591 & 283,79 & 0,000 & YES \\
\hline & 4 & 149 & 644,37 & 0,000 & YES & 5,986 & 565,07 & 0,000 & YES & 6,991 & 511,78 & 0,000 & YES & 4,181 & 377,53 & 0,000 & YES & 11,787 & 2606,85 & 0,000 & YES \\
\hline & 5 & 7,430 & 128,42 & 0,000 & YES & 8,707 & 194,45 & 0,000 & YES & 7,076 & 145,74 & 0,000 & YES & 6,592 & 314,51 & 0,000 & YES & 15,233 & 756,75 & 0,000 & YES \\
\hline & 6 & 5,982 & 30,83 & 0,000 & YES & 10,650 & 69,72 & 0,000 & YES & 5,975 & 55,03 & 0,000 & YES & 8,269 & 82,07 & 0,000 & YES & 15,329 & 230,30 & 0,000 & YES \\
\hline 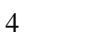 & 5 & 4,140 & 141,71 & 0,000 & YES & 5,288 & 171,67 & 0,000 & YES & 2,058 & 182,02 & 0,041 & YES & 3,965 & 248,11 & 0,000 & YES & 7,726 & 733,73 & 0,000 & YES \\
\hline 4 & 6 & & 31,84 & & YES & 8,294 & 65,03 & & YES & 2,874 & 61,03 & 0,006 & YES & 6,643 & 70,25 & 0,000 & YES & 10,822 & 227,06 & 0,000 & YES \\
\hline 5 & 6 & 1,804 & 43,29 & 0,078 & NO & 4,106 & 104,27 & 0,000 & YES & 1,419 & 81,77 & 0,160 & NO & 3,992 & 97,27 & 0,000 & YES & 5,652 & 321,53 & 0,000 & YES \\
\hline
\end{tabular}

